\title{
Management of Florida Scrub for Threatened and Endangered Species
}

Bruce A. MacAllister and Mary G. Harper

Florida Scrub on military installations supports a number of land uses including the Department of Defense (DoD) training and testing mission and threatened, endangered, and sensitive species (TES) conservation. This report documents strategies to manage TES and their habitat on a plant community basis, using methods that apply to multiple species occurring in scrub within the state of Florida.

This report provides ecological descriptions of the community, along with available information about community occurrence on DoD installations in Florida.
Known occurrences of plant and animal TES are also included. Known and potential impacts to the integrity of the community as TES habitat and to associated species are reported. Impacts are related to habitat fragmentation, and changes in community composition, structure and function due altered fire regime, hydrologic patterns, groundcover integrity or the invasion of exotic species. Management recommendations are made within as ecosystem based, adaptive management context. 
SF 298 


\section{Executive Summary}

Although the primary mission of the Department of Defense (DoD) is military preparedness, DoD is also charged with managing the natural resources found on more than 25 million acres across the U nited States. Recent DoD initiatives such as the U.S. Army Environmental Strategy into the 21st Century direct each branch of thearmed forces to comply with all environmental laws. This includes protecting habitat for threatened and endangered species (TES; both listed and candidate species). DoD requires installations to conserve natural resources for future generations by enacting and practicing sound management and conservation policies on lands that must also support military training exercises and weapons testing or storage.

This report is to be used by DoD natural resource policy makers, installation land managers, and the natural resource research community, in conjunction with associated documents produced under this SERDP work unit (e.g., Trame and Harper 1997; Trame and Tazik 1995) to (1) devel op ecosystem-based approaches to describe natural communities and TES habitat in relation to military activities, (2) evaluate military-related effects on those communities, (3) develop community-based strategies for supporting both military land useand TES habitat management, and (4) develop management solutions for military impacts to natural communities when management for TES habitat is a priority for a particular location.

This report focuses on Florida scrub, a rare and rapidly disappearing community found on dry, sandy soils that make up ancient dune systems. This community lies within a matrix of associated xeromorphic plant communities (Iongleaf pine, sandhill, and xeric hammock) and surrounding wetland areas. All of these communities are interconnected physiographically and are dependent on fire for persistence. Florida scrub, however, has adapted to a different fire regimethan the other communities in this association. Fires in scrub occur at longer intervals and are more catastrophic than fires occurring in the other communities.

The scrub community is found mainly in Florida and is typically dominated by a dense layer of evergreen or nearly evergreen oak, or Florida rosemary (Ceratiola ericoides) shrubs, with an open to closed canopy of sand pine (Pinus dausa). Depending on the fire history, the sand pines may or may not be present. Ground 
cover is generally sparse and may be dominated by ground lichens. Bare patches of sand are common. The sandy soils supporting scrub are dry and nutrient poor. Nonetheless, at least 13 TES plants and 10 TES vertebrates can be found in the small fragments of scrub that can still be found on a number of military installations in Florida.

Many remaining scrub communities have been degraded by past management practices, land uses, and other human disturbances. Agriculture and forestry practices havealso taken their toll on scrub in areas not managed by DoD. Human encroachment and development have been extensive, due to a burgeoning human population in Florida and the fact that these communities typically occupy areas of high real estate value. Fragmentation of scrub habitat has resulted in the extirpation of flora and fauna that are more common in contiguous habitat, due to increased land use pressures.

To protect remaining TES populations, larger patches of scrub should be restored and maintained in the context of TES habitat requirements. Degraded areas adjacent to high-quality Florida scrub can be enhanced to further increase TES habitat, thereby reducing the impacts of fragmentation. These actions will permit more effective management at the landscape level. Activities that interrupt TES populations and the natural processes that sustain them should al so be avoided, or an alternative location for the activity should be sought.

Fire suppression over the past 80 years has effectively changed the natural processes and composition of many fragments of Florida scrub. A number of rare plants in this ecosystem require the structure of open patches of sand and vegetation that are created under a natural fire regime. These plants will not survive when the shrub layer grows to the point that the open patches are shaded out. Available information (Myers 1990; Christensen 1985, 1988) suggests that prescribed burning is necessary for maintenance of most scrub communities in Florida. There is no specific fire return interval applicable to all scrubs. Management guidelines should reflect the desire to maintain different stages of plant growth across the entire landscape, as each stage offers important structural attributes to different TES. Prescription fires should mimic patchy natural burn patterns in which areas of burned vegetation are not contiguous.

Recommendations by Wool fenden and Fitzpatrick (1991) for a fireinterval adequate to maintain prime Florida Scrub jay habitat are suggested as a guideline for some of the other animal and plant TES. However, the catastrophic nature of fire in scrub often makes burning this habitat dangerous, especially when it is in close proximity to residential areas and other areas easily damaged by an escaped fire. 
Smoke management is also a problem. The techniques recommended for burning Florida scrub are addressed in Chapter 5 . Some alternative burning strategies to use when dealing with fire and smoke management problems are also discussed. Mechanical disturbances may be another suitable substitute for high intensity fire in the maintenance of scrub.

Unlike many other habitats, altered hydrology is not likely to bean issue for plants native to scrub due to their high tolerance to drought stress. Florida scrub also tends to be less vulnerable than other communities to invasion by exotic species, by virtue of the demanding physical environment in which it grows. However, activities that disturb scrub soils can increase susceptibility of scrub to invasion by species not native to the community. Activities such as fire suppression, constructing fire plow-lines, and road building promote invasion by exotics. Removal of exotic species also entails physical disturbance, which can destroy the very habitat managers are trying to improve. These practices should be implemented in such a way that they limit damageto theroot systems of sensitiveTES plants. Chemical removal (i.e., the use of herbicides) can be used when absolutely necessary but care must be taken near TES populations and in close proximity to wetlands.

Natural scrub communities in Florida are biologically diverse ecosystems. They provide habitat for at least 23 TES, many of which are protected under the Endangered Species Act. Under some circumstances, it is desirable to maintain high-quality natural communities to providehabitat for multiplenativespecies over large areas. In particular, this strategy works well as part of the Integrated Natural Resources Management Planning (INRMP) process, within an ecosystem management framework. The recommendations made in this report are intended to be applied in areas where TES conservation is the primary focus of land management, but may also support military training objectives. 


\section{Foreword}

This study was conducted for the Strategic Environmental Research and Development Program under a subset of Work Unit SERDP 507/45678, "Threatened, Endangered and Sensitive Resources." Mr. Bradley P. Smith is ExecutiveDirector, SERDP. The technical monitor was Dr. Femi A. Ayorinde, Cleanup and Conservation Program Manager.

The work was performed by the Natural Resource Assessment and Managment Division (LL-N) of the Land Management Laboratory (LL), U.S. Army Construction Engineering Research Laboratories (CERL) and by theNatural Resources Division (NRD), Environmental Laboratory (EL), U.S. Army Engineer Waterways Experiment Station (WES). The CERL principal investigator was Ann-Marie Trame. The WES principal investigator was Chester O. Martin. Bruce A. MacAllister was employed as a Scientist II and Mary G. Harper was employed as a Research Associate, under an interagency agreement with the U.S. Forest Service, Rocky Mountain Rangeand F orest Experiment Station, and Col oradoState University. Dr. Harold E. Balbach is Chief, CECER-LL-N; Dr. J ohn T. Bandy is Operations Chief, CECER-LL. The CERL technical editor was Gloria J . Wienke, Technical Information Team.

The Director of CERL is Dr. Michael J . O'Connor. 


\section{Contents}

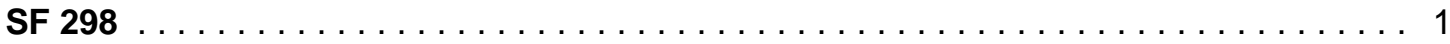

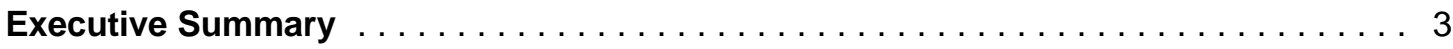

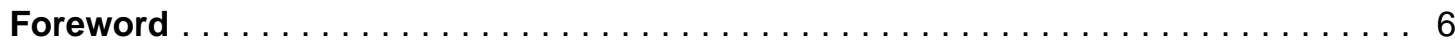

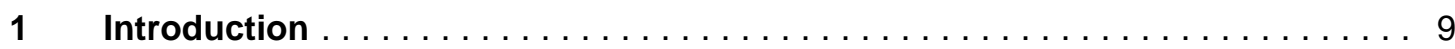

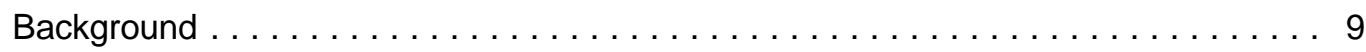

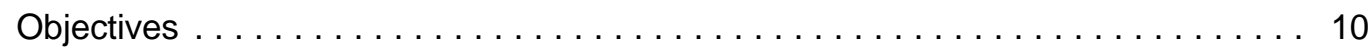

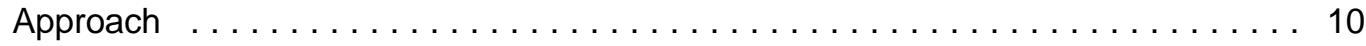

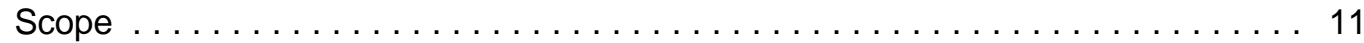

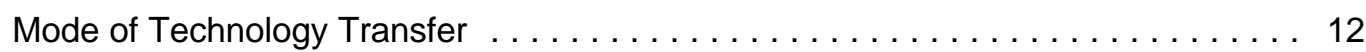

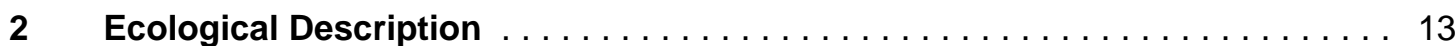

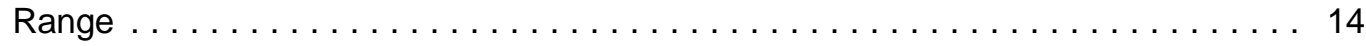

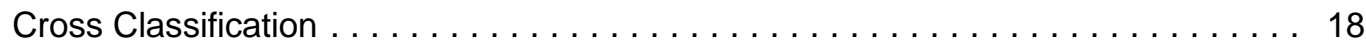

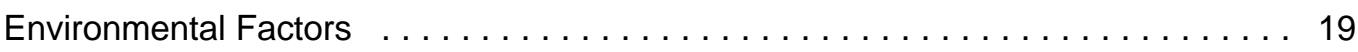

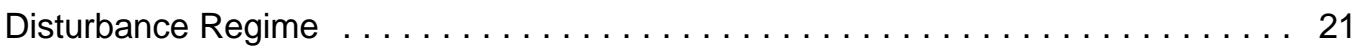

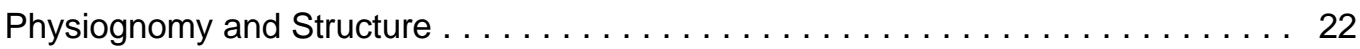

Commonly Associated Plant Communities ....................... 23

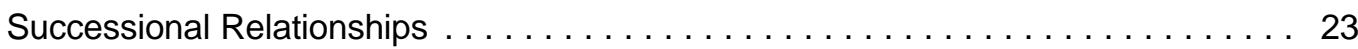

Biological Composition $\ldots \ldots \ldots \ldots \ldots \ldots \ldots \ldots \ldots \ldots \ldots \ldots \ldots \ldots$

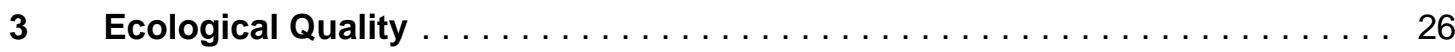

Biodiversity and TES ...................................... 26

The Use of a Community Quality Assessment . . . . . . . . . . . . . 30

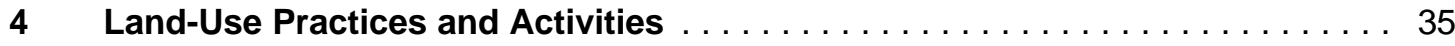

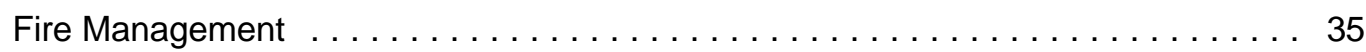

Agricultural and Forestry Practices $\ldots \ldots \ldots \ldots \ldots \ldots \ldots \ldots \ldots \ldots \ldots \ldots \ldots \ldots \ldots \ldots \ldots \ldots$

Development ....................................... 36

$5 \quad$ Impacts and Management Recommendations $\ldots \ldots \ldots \ldots \ldots \ldots \ldots \ldots$

Fragmentation and Land-Use Conversion $\ldots \ldots \ldots \ldots \ldots \ldots \ldots \ldots \ldots \ldots \ldots$

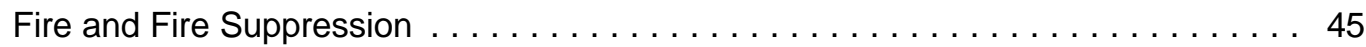

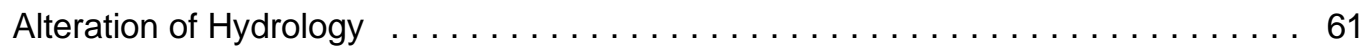

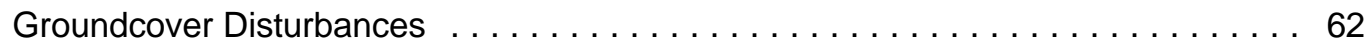

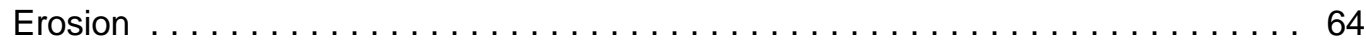


Exotic Species . . . . . . . . . . . . . . . . . . . . . . . . . . . . . 64

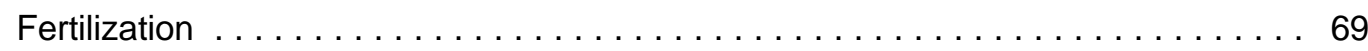

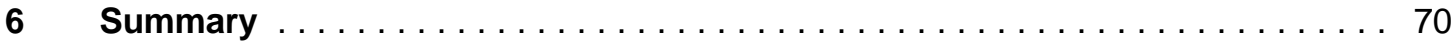

Appendix A: Community Quality Evaluation and Management . . . . . . . . . 73

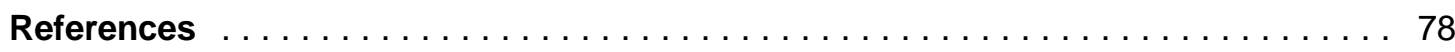

Professional Communications $\ldots \ldots \ldots \ldots \ldots$

Abbreviations and Acronyms $\ldots \ldots \ldots \ldots \ldots \ldots$

Distribution 


\section{Introduction}

\section{Background}

Florida scrub is a rare and rapidly disappearing community that can be found on dry, sandy soils lying within a matrix of associated xeromorphic plant communities (longleaf pine sandhill and xeric hammock [a forest type dominated by broadleaf evergreens]) and surrounding wetland areas (United States Fish and Wildlife Service [USFWS] 1995). All of these associated ecosystems are dependent on fires for persistence and are interconnected physiographically. These communities are found on a number of military installations where they support a variety of uses, such as the Department of Defense (DoD) training and testing mission, threatened, endangered and sensitive species (TES)* conservation, and recreation/open space. Some scrub may sustain intense land-use pressures, while other areas may serve simply as a buffer zone between military operations and civilian lands. Despitethe fact that the primary mission of the DoD is military training and testing, installations are required to maintain robust populations of TES species into the foreseeable future.

Historically, management practices that protectTES, plant communities, and other natural resources reflected the need to address immediate and local problems. Although this approach can be rewarding and effective for an individual installation, it predudes any organized understanding of land-use impacts, or sharing of lessons learned, and can sometimes lead to repeated, inefficient efforts to solve similar problems throughout a region of the country. Duplication of effort needs to be reduced or eliminated.

This report is one product of an inter-laboratory effort between the U.S. Army Construction Engineering Research Laboratories (CERL) and the U.S. Army Engineer Waterways Experiment Station (WES) to generate habitat-based management strategies for TES on DoD lands in the southeastern United States

\footnotetext{
* The acronym "TES" instead of "T\&E Species"will be used in this report to conform to standard DoD terminology. We also include Candidate Species (former C1 Species), defined as those plant and animal species that, in the opinion of the United States Fish and Wildlife Service (USFWS) or National Marine Fisheries Service, may qualify for listing as threatened or endangered pursuant to the Endangered Species Act; and Species of Concern, or former C2 species.
} 
(Strategic Environmental Research and Development Program [SERDP] work unit "Regional Guidelines for Managing T\&E Species Habitats"; Martin et al. 1996). This effort is directed at developing strategies to manage TES and their habitats on a plant community basis, using methods that apply to multiple species and that apply across the southeastern United States. Any increase in understanding of the habitat requirements of listed TES will assist training and natural resource personnel in complying with the Endangered Species Act (ESA), while giving them the information they need to reduce restrictions on the military mission. Furthermore, the results detailed in this report suggest that a great deal of additional effort is required before the process will be guided by solid scientific information (as required by the ESA).

\section{Objectives}

The objectives of this research were to compile known information, identify gaps in knowledge, and stimulate future research efforts on the potential positive and negative effects of human activities on the plant communities that serve as highquality habitat for TES in the southeastern United States.

This SE RDP work unit, in particular, was undertaken toreduce duplication of effort towards conservation of TES within the southeastern region. It is intended that this review of information be used to improve the ecological and economic effectiveness of TES habitat management. By understanding the ecological requirements of TES and the environmental resilience or sensitivity of TES habitats, installations acquire increased control over TES management and landuse decisions.

\section{Approach}

To identify potential impacts, researchers reviewed the available literature and conducted interviews with community ecologists throughout the southeastern United States, with an emphasis on interviewing those people who have been involved in plant TES and plant community survey work on military installations. Potential impacts were also discussed with military natural resources personnel, botanists, community ecologists, and military contractors, and the staff at other environmental organizations, such as The Nature Conservancy (TNC) or state Natural Heritage Program (NHP). Information also was taken from installation TES survey reports in which impacts and management were addressed. Land Condition Trend Analysis (LCTA) data, Land Rehabilitation and Maintenance 
(LRAM ) reports, and academic and Federal agency literature on recreational effects on plant communities were also reviewed.

\section{Scope}

Within the context of the larger DoD mission, TES populations can be maintained through the following framework: (1) identify mission requirements, (2) identify TES requirements, (3) identify ideal compromi ses for meeting both TES and mission requirements, and (4) pursue these compromises and develop realistic, workable plans. The fourth step should be executed through professional management of TES populations, at the installation level, to reduce restrictions on the military mission. This document partially contributes to the total TES and land management process. It provides information to assist in identifying the needs of TES (step 2), and perhaps will assist in identifying options for compromise as well (step 3). The content of this report is not intended to provide the "bottom line" for management of TES on military lands - only to provide information from literature review for the consideration of installation land managers.

This report focuses on plant communities because they provide habitat for multiple species. By managing for plant communities, DoD has the opportunity to conserve multipleTES simultaneously. Plant communities are less ambiguous entities than complete ecosystems, and have been described and cataloged for many decades by ecologists and biogeographers. They provide a useful basis on which to understand and manage the natural systems that support military training and other land uses.

Scrub communities are closely associated with xeric longleaf pine sandhills and other pyrogenic plant communities. Earlier reports from this SERDP work unit indude summaries of management recommendations for a number of these associated communities (Harper et al. 1997 and Harper, Trame, and Hohmann, 1998). While conducting research for this report, researchers found management recommendations pertaining to species inhabiting both scrub and longleaf pine woodlands that tended to be biased toward longleaf pine. Some of the species mentioned herein, particularly the vertebrate TES, are found in several other community types that may or may not be associated with Florida scrub. However, any management recommendations that pertain to these organisms are written solely within the context of ecosystem management for the scrub community.

The intent of this document is to provide managers with the information needed to develop community-based, site-specific management plans for Florida scrub on installations within the state of Florida. An assessment of impacts has been 
provided. Based on this assessment and the current quality of the community, recommendations for management, restoration, and land use have been provided.

Due to the scope of this report, specific recommendations are intended to be considered only for areas that trainers and resource managers recognize and manage as endangered species habitat. These recommendations are not intended to be applied across entire DoD installations (e.g., on areas required for use as maneuver training zones).

\section{Mode of Technology Transfer}

This report is to be used by DoD natural resource policy makers, installation land managers, and the natural resource research community, in conjunction with associated documents produced under this SERDP work unit (e.g., Trame and Harper 1997; as well as Trame and Tazik 1995) to (1) devel op ecosystem-based approaches to describenatural communities and TES habitat in relation to military activities, (2) evaluate military-related effects on those communities, (3) develop community-based strategies for supporting both military land use and TES habitat management, and (4) devel op management solutions for military impacts tonatural communities when management for TES habitat is a priority for a particular location.

Results of this report will be presented at the annual SERDP Symposium. In addition, this and companion volumes have been identified for life-cycletechnology demonstration and support in the Conservation Technology Infusion effort being developed under the Army's environmental science and technology process. 


\section{Ecological Description}

Scrub communities have numerous synonyms, many of which describe the dominant shrub of the assemblage. Oak scrub, rosemary scrub, palmetto scrub, sand pine scrub and, in somecases, coastal scrub and scrubby flatwoods are all used to describe different variations of this habitat. Differences in microdimate, topography, fire regime, and stages of succession are also responsiblefor the variety of forms documented for this community. For this report, these assemblages will be grouped together under the generic terms "scrub" and "Florida scrub."

Florida scrub is often found within a matrix of pyrogenic plant communities, although often protected by adjacent wetlands. Thesurrounding landscapeis often dominated by longleaf pinewoodlands. Historically, abrupt ecotones were reported between the two communities where they occurred adjacent to each other. The two communities are now known to be dissimilar in composition and structure based on differences in soils and disturbance regimes; allelopathy (the ability to produce chemicals that inhibit growth of other plants) may play an important role as well (reviewed in Myers 1990).

Florida scrub is distinguished here from maritime shrub al ong the Atlantic coast (Gehl hausen, Harper, and Trame 1998). Maritime shrub is considered to be an intermediate stage between shoreline dunes/interdunal swales, and the more protected maritime forests. Along the Atlantic coast, maritime shrub communities are dominated by wax myrtle (Myrica cerifera) and yaupon holly (Ilex vomitoria; reviewed in Gehlhausen, Harper, and Trame 1998). On the Panhandle of Florida, this same community is characterized by Florida rosemary (Ceratiola ericoides), scrub oaks, and sand pine (Myers 1990); this community is included here as one type of Florida scrub, referred to as "coastal scrub." It differs from inland scrub in that it is often younger in origin, being partially or wholly structured by physical coastal disturbances instead of fire disturbance, and supporting fewer endemic species (USF WS 1998).

This characterization of Florida scrub excludes scrubby flatwoods, which are generally thought to be intermediate between scrub and longleaf pine woodlands. Scrubby flatwoods aresimilar to scrub communities because they can be dominated by evergreen, sclerophyllous shrubs. However, wiregrass and other herbaceous 
species found in pine flatwoods also occur in scrubby flatwoods (Stout and Marion 1993). The Florida Natural Areas I nventory (F NAI) and the Florida Department of Natural Resources (FDNR) (1990) recognize this as a distinct community, as it is often associated closely with mesic flatwoods, and occupies sites with a higher water table than does scrub.

This document covers the ecology of, impacts to, and management for tracts of coastal and inland Florida scrub. However, most research related to rare species conservation and fire management in Florida scrub has been conducted in inland communities, thus, management recommendations will reflect that bias. We advocate additional research into the management needs of coastal Florida scrub (FNAI 1994b).

\section{Range}

\section{Origins and Historical Range}

Scrub-like vegetation began to appear in the fossil record in the early Tertiary. This once vast ecosystem originated in the southern Rockies and northern Mexico, spreading east along the Gulf Coast to Florida (Mark Deyrup, Entomologist, Archbold Biological Station, FL, professional discussion, 14] anuary 1998 [hereafter referred to as M. Deyrup, $14 \mathrm{~J}$ anuary 1998]; Axelrod 1958). During the late Pleistocene, the Earth's climate was cooler and dryer than it is today and scrub vegetation was probably widespread on the Florida peninsula (Myers 1990). As the Earth's climate began to warm and become more moist, much of the ancient scrub eventually became southern pine forest. Scrub-like flora still existed on the xeric soils and coastal dune ridges where drought stress and nutrient-poor soils prohibited many species from gaining a foothold (Myers 1990). Between 5,000 and 7,000 years ago, the Earth's climate became even more moist as water levels rose (Myers 1990). Electrical storms became common. Wild fires ignited by lightning, and fires intentionally set by early humans, gradually selected for fire-dependent species, which dominated the landscape upon the arrival of European settlers.

\section{Current Distribution}

Today, this rare community type is limited almost exclusively to the state of Florida, although examples of similar communities do occur elsewhere. Florida scrub still occupies excessively well-drained soils associated with ancient coastal dune systems. Coastal and inland scrub communities can be found on the peninsula, but stands also occur on the panhandle of F lorida, al ong the Gulf coast 
(Myers 1990). A few examples exist as far west as Mobile Bay in Alabama (Stout and Marion 1993). A single stand of Florida scrub has been discovered in Mississippi, and similar communities occur in parts of southern Georgia (Stout and Marion 1993).

Scrub always occupies dry, sandy, nutrient-poor soils that are found in a number of places in Florida. The range of inland peninsular scrub is generally restricted to a complex of sand ridges and ancient dunes running north and south from Clay and Putnam counties to Highlands county (Myers, 1990), with a few fragments persisting on military installations where residential development and citrus cultivation have been limited. Peninsular coastal scrub is found on both the Atlantic and Gulf coasts. Panhandle scrubs are restricted to a narrow strip along the Gulf coast and on some barrier islands (Figure 1).

Northernmost examples of coastal peninsular scrubs in Florida occur on the east coast in St. J ohn's County near Durbin and on the west coast in Levy County near Cedar Key. Southernmost scrub communities in Florida once occurred on the west coast at Marco I sland in Collier County and on the east coast in northern Broward County, but these have been largely lost to devel opment and will soon beextirpated (Myers 1990).

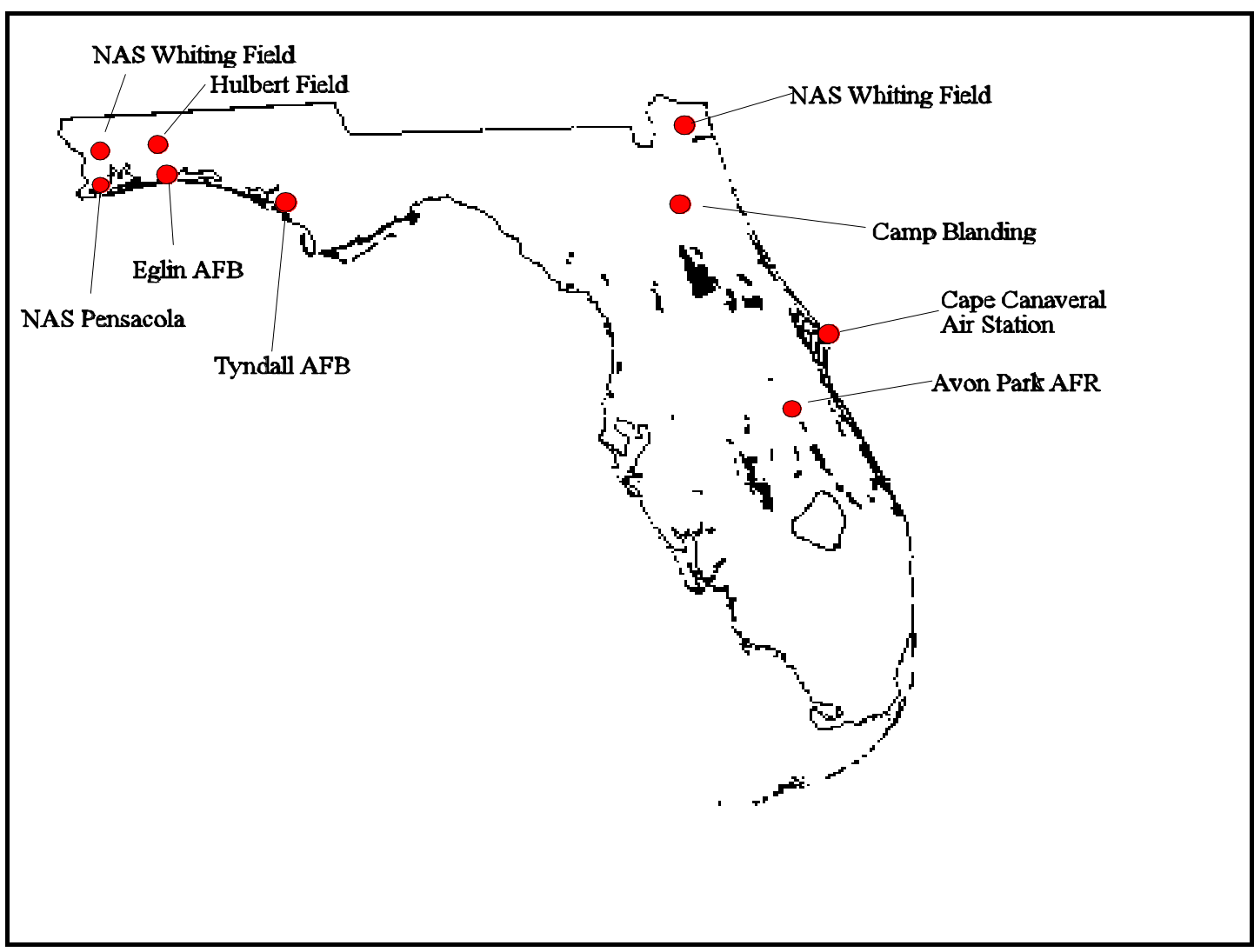

Figure 1. General distribution of Florida scrub and military installations on which the community occurs. 
Most remaining scrub communities range in area from 40.4 to 242 ha (Stout and Marion 1993). The largest block of Florida scrub is inland scrub; named the Big Scrub complex, it occurs in and around the Ocala National Forest in north-central Florida. Most of this 84,987-ha region is managed for the production of wood products from sand pine (Stout and Marion 1993, Myers 1990). The southern end of the Lake Wales Ridge, FL, in Polk and Highlands counties, supported another large expanse of Florida scrub that occurred in a mosaic with high pine communities, but morethan 70 percent of the southern Lake Wales Ridge xeric uplands have been converted to other land uses (Myers 1990). F ew remaining examples of scrub on the Lake Wales Ridge are larger than a few hundred acres; but the largest is 2866 acres (USFWS 1995). An estimated 64 percent of Florida scrub on Lake Wales, Lake Henry, and Winter Haven ridges of central peninsular Florida have been lost to development since the time of E uropean settlement (N oss, LaRoe, and Scott 1992).

\section{Occurrence on Military Installations}

Florida scrub has been documented on at least eight military installations in Florida (Table 1). The quality of Florida scrub on installation lands varies with land use history.

Avon Park Air Force Range has over 5,500 acres of scrub in three areas: Bombing Range Ridge, the Osceola Plain, and the Kissimmee River Valley escarpment (TNC 1994). These areas of scrub are all intact and relatively undisturbed. A number of TES are found on Avon Park due to the relatively large fragments of scrub community still found there.

Two forms of scrub are found on Camp Blanding Training Site. A patchy canopy of sand pine over dense thickets of oaks and rusty lyonia occurs at Lowry Lake scrub and Kingsley scrub, while Blue Pond Scrub and Gidding scrub lack the sand pine overstory (FNAI and TNC 1995). Although theseareas are disjunct and do not form large blocks of scrub habitat, they are still able to sustain populations of TES.

Xeric pine/oak scrub habitat occurs in a small area within the Rodman target range of Naval Air Station (NAS) Cecil Field. Although some species have not been seen in this area in the past 10 years, gopher tortoises (Gopherus polyphemus) and a number of rare scrub herbs can still be found there. Several avian TES also pass through occasionally (Lloyd Cruize, Natural Resource Manager, NAS, Cecil Field, J acksonville, FL, professional discussion, 29] anuary 1998 [hereafter referred to as L. Cruize, 29 J anuary 1998]). 
Table 1. Occurrence of Florida scrub communities on military installations in the State of Florida.

\begin{tabular}{|c|c|c|c|}
\hline State & Branch & Installation & Reference \\
\hline \multirow[t]{10}{*}{$\mathrm{FL}$} & \multirow[t]{5}{*}{ Air Force } & Avon Park Air Force Range (AFR) & Howie (1994) \\
\hline & & Cape Canaveral Air Station & FNAI (1998) \\
\hline & & Eglin Air force Base (AFB) & FNAI (1994b) \\
\hline & & Hurlburt Field & Labat-Anderson INC. (1994) \\
\hline & & Tyndall AFB & FNAI (1994a) \\
\hline & Army & Camp Blanding & $\begin{array}{l}\text { FNAI and The Nature Conservancy } \\
\text { (TNC; 1995) }\end{array}$ \\
\hline & \multirow[t]{4}{*}{ Navy } & Naval Air Station (NAS) Cecil Field & Burst (1988) \\
\hline & & $\begin{array}{l}\text { NAS Pensacola and Outlying Field, } \\
\text { Bronson }\end{array}$ & Burst (1995a) \\
\hline & & NAS Whiting Field & Burst (1995b) \\
\hline & & NAS Jacksonville & $\begin{array}{l}\text { Environmental Service and Permitting, } \\
\text { Inc. (1990). }\end{array}$ \\
\hline
\end{tabular}

Eglin Air Force Base (AFB) supports remnant coastal scrub on barrier islands and on the mainland. Inland scrub occurs on the southeastern portion of the base. These include an area known as "Scrub Hill" which runs along Eglin Range Road 205. A parcel of land northwest of the intersection of Range Road 259 and Florida State Highway 98 and a patch between Eagle Creek and Little Trout Creek also support inland scrub (FNAI 1994b).

Tyndall AFB harbors a number of small patches of high-quality coastal scrub on Crooked I sland and on the peninsula comprising the majority of the Air F orce Base itself. One mature patch of scrub is located on the southern edge of E ast Bay, near Strange Bayou. A number of element of occurrence records for scrub habitat on file with the FNAI occur here and on other parts of the base (FNAI 1994a).

Several fragments of coastal scrub are located around the edges of F orrest Sherman Airfield at NAS Pensacola. Another mosaic of tiny patches of scrub and scrubby flatwoods surrounded by a matrix of mesic flatwoods is located just north of Trout 
Point. These are areas of relatively high quality, supporting a canopy dominated by sand pine and a fair amount of lichens covering the ground. Some hurricane damage can be seen in the older trees and this has resulted in numerous gaps in the canopy (FNAI 1998).

Florida scrub is also found on Cape Canaveral Air Station. This community occupies the Welaka Sand Ridge that lies on the western edge of the Canaveral Peninsula. The canopy here is 4 to $7 \mathrm{~m}$ tall with a few large diameter sand pines emerging from the canopy. Another patch with a large compliment of species is located on the isthmus of the Canaveral Peninsula, east of the Banana River and north of Launch Complex 37. Other patches of coastal scrub and Oak scrub occupy relict dune ridges around the installation (FNAI 1998).

\section{Cross Classification}

Scrub is defined as a shrub community dominated by a layer of oaks or Florida rosemary, or both, and with or without a pine overstory. Open areas of sand are dispersed between the thickets. Florida scrub is synonymous with the "sand pine scrub" community of Stout and Marion (1993) and Christensen (1988), the "scrub" community described by Myers (1990) and by the GuidetotheN atural Communities of Florida (FNAI and FDNR 1990), and is thesame as the Florida scrub community described by the U.S. Fish and Wildlife Service (1995). Georgia's "dwarf oakevergreen shrub forest," "evergreen scrub forest," and "evergreen scrub-lichen forest" communities (Wharton 1978) aresimilar to F lorida scrubs without sand pine as a component of the modern flora (Stout and Marion 1993).

Abrahamson et al. (1984) divided the scrub community into two distinct types. They identified the oak understory type as a three-layered community. In this version, the scrub has a lower layer of saw palmetto (Serenoa repens) and scrub palmetto (Sabal etonia), an upper shrub layer consisting of scrub oaks, rusty lyonia (Lyonia ferruginea) and/or scrub hickory (Carya floridana), and an overstory of sand pine (Pinus clausa). Herbaceous plants tend to be scarce in this type. The rosemary type of this community is characteristic of drier ridges and knolls, with more herbaceous ground cover and open patches of sand. This version of scrub is identified by the predominance of rosemary and a pine overstory that is much more open. Other synonyms for this community include: sand scrub, rosemary scrub, and oak scrub (FNAI and FDNR 1990); in addition, slash pine scrub may be used if the overstory consists of this species of pine (Myers 1990). 


\section{Environmental Factors}

\section{Topography}

Inland peninsular scrub communities occur along a complex of windswept sand ridges and ancient dune fields that once defined the coast of F lorida. These make up the majority of remaining scrub habitat. Coastal peninsular scrub communities occur along the Atlantic and Gulf coasts and occupy dune systems associated with recent Pleistocene shorelines. Panhandle scrubs occur as narrow strips al ong the Gulf coast and its barrier islands (Myers 1990). Scrub generally occurs on areas of excessively drained upland soil that are protected from frequent fires by virtue of their position in a matrix of lakes, swamps, or other lower lying wetlands (USFWS 1995).

\section{Soils / Nutrients}

One of the elements that define scrub habitat and its distribution on the landscape is the soil upon which scrub vegetation grows. Most scrub soils supporting this community are entisols, derived from quartz sand. Some scrub communities al ong the Atlantic Costal Ridge occur on Cocoa sand, a soil series that forms over coquina and is classified as an alfisol (Paul Schmalzer, Senior Field Ecologist, Dynamac Corporation, professional discussion, 12 May 1998 [hereafter referred to as P. Schmalzer, 12 May 1998]). They are al most devoid of silt, clay, and organic matter and arether efore nutrient-poor. No distinguishablesoil horizons can be seen in the soil profile. It consists of a single, undifferentiated layer of sand ranging in color from pure whiteto a yellow or buff tone, depending on the age. As water percolates through the soil, organic acids are produced by the decay of forest litter. These acids chemically bleach iron oxide stains and leach organic matter out of the soil, leaving the siliceous sand its characteristic light color. The longer this bleaching action has gone on, the older the soil. Scrub communities that grow on very light or white soil are therefore older than those that grow on soils that are more yellow in color (Myers 1990).

Regardless of age, scrub soils are excessively well drained. The soil's parent material is composed of loose quartz sand. Therefore, water drains rapidly through the substrate creating very xeric conditions for which plants must be suited (FNAI and FDNR 1990). The root systems of most scrub plants are adapted to survive in the xeric conditions caused by these sandy soils. Many plants have fine, shallow roots that facilitate nutrient capture close to the surface of the ground. But they also have deep tap roots so they can access ground water at considerable depths (Myers 1990). Drought stress does not seem to be a problem for scrub-adapted 
vegetation because of these deep root systems. Nutrient deficiencies aremore often a problem for scrub vegetation. Because most of the nutrients in scrub ecosystems are tied up in the biomass, very little is left in the soil and available to young plants. Therefore, only plants that are hearty enough to survive under this nutrient stress will grow on scrub soils. Some scrub plants may use allelopathy to avoi d competition for scarcenutrients (Myers 1990). Thesefactors may explain why few exotic species have been able to establish themselves in areas of undisturbed scrub.

The greatest consequence of such poor soil conditions may be a reduction in propagation by seed in scrub species. Many species spread vegetatively by resprouting from root stocks, rhizomes, and burls protected from fires beneath the soil surface (Christensen 1988). Some species, such as sand pine and rosemary, cannot resprout in this way and must rely on seeds for regeneration. These species have adapted special mechanisms to facilitate germination in such hostile conditions.

Soil crusts may affect nutrient and water regimes in the uppermost region of the soil profile. These soil crusts consist of algae, cyanobacteria, fungi, bacteria, and the early stages of lichens and mosses. Although unseen, these micro-organisms form a fragileaggregate with the soil particles at the ground surface and contribute to the carbon content of the soil (Christine Hawkes, GraduateStudent, Department of Biology, University of Pennsylvania, professional discussion, 21 May 1998 [hereafter referred to a C. Hawkes, 21 May 1998]). They may al so play a role in determining the distribution and abundance of certain vascular plants on nutrientpoor scrub soils due to their suspected ability to fix nitrogen or hold water. These crusts areextremely susceptibletodisturbance. Research is underway to determine exactly what role these structures play in this ecosystem (C. Hawkes, 21 May 1998).

Recently, scientists have been looking at the relationship between plants and soil microbes to see if a symbiotic relationship exists. Relationships of this nature are well studied in other ecosystems, but the micro-organisms living in scrub soils are not adequately understood. Anderson and Menges (1997) suggested that the investment in a mycorrhizal system may be disadvantageous to scrub plants if it will not increase the availability of nutrients that arelimiting tothe plants' growth. They found a low level of colonization by bacteria in the root systems of four scrub plants and determined that the mycorrhizal relationship between these plants and soil bacteria is not well developed; the scrub plants they studied were not enjoying an increased uptake of any nutrients that resulted from microbial activity in their root systems. These organisms may exist simply as a semi-benign parasite. 


\section{Disturbance Regime}

\section{Physical Coastal Disturbances}

Coastal scrubs appear to be maintained by wind and other physical disturbances to a greater extent than inland scrubs. The scrub community is found on the ol dest dune ridges al ong the Panhandle coast, and thus may persist for a very long time. However, as distance from the harsh coastal environment increases, abundance of sand pine also increases. Additional species begin to appear as well, including large-leaved jointweed (Polygonella macrophylla; J ohnson, Muller, and Bettinger 1992), a species of concern (SOC) recognized by the U.S. Fish and Wildlife Service.

\section{Fire Regime}

The fire regime is determined by the frequency of fires in an ecosystem (fire return interval), the intensity of the fire, its type and the spacial pattern of the burn area (Christensen 1985; Parker 1989). These factors interact with each other to exert selective pressure on the reproductive strategies in plants, but can also act independently to influence the quality, quantity, and timing of reproduction in plants (Ostertag and Menges 1994).

Most scrub plants fall into one of four guilds, each characterized by a certain reproductive strategy: resprouters (mainly woody shrubs), resprouters and seeders (small statured shrubs, palms, and herbaceous perennials), obligateseeders (mainly herbs), and resprouters and clonal spreaders (Menges and Kohfeldt 1995). Each of these strategies has advantages and disadvantages in reproduction but each attempts to maximize species survivability according to a specific fire regime.

Seeders typically do not survive fire and must rely on either a persistent seed bank or a method for distant dispersal to persist in a patch. Herbaceous plants that rely on seed regeneration may be most susceptible to localized extinction from fire return intervals that are either too short or too long (Quintana-Ascencio and Menges 1996). If fire returns too frequently, individuals may not have time to reach reproductive maturity; if fire return intervals are too long, many herbaceous plants will be outcompeted by dominant shrubs and/ or trees. For these species, successful dispersal between habitat patches may be important for long-term persistence (Quintana-Ascencio and Menges 1996).

Resprouters have an advantage in that they can recover very quickly oncea firehas passed, but dispersal to other patches may belimited. Thosespecies that reproduce 
by both seeding and resprouting practicea bet-hedging strategy. They areensuring their survival no matter what the fire return interval.

Unlike surrounding longleaf pine woodlands, scrubs are characterized by long periods between fires. The natural fire return interval for inland scrub may be every 30 to 60 years (Christensen 1988). Myers (1990) states that typical natural fire intervals may be every 10 to 60 years. Because scrubs lack much of the dried grasses, fine textured pine needles, and other flashy fuels that ignite and burn easily, they usually have a high heat of ignition and are difficult to burn. This is evident in the long period of time between fires. The poor productivity of scrub soils accounts for the slow accumulation of leaf litter and duff. This fuel builds up at a faster rate in more productive communities (like longleaf pine woodlands) and results in more frequent fires. In general, scrub acts as a barrier to the spread of fire due to its inability to burn. When these areas do burn, the fires are almost al ways catastrophic because they result in a crown fire that kills the pine overstory outright and burns back the oak shrub layer to ground level (Christensen 1988). Conflagrations result when high fuel levels are combined with severe burning conditions: high temperatures, low humidity, low fuel moisture, and sustained winds. Yet even under these conditions, fires usually start in adjacent plant communities and spread through the scrub, leaving a patchy burn area in which some places are completely charred while others remain untouched by the fire.

\section{Anthropocentric Disturbances}

When fires are suppressed, the Florida scrub community may be converted to a pioneer xeric hammock, characterized by tree-sized oaks and a loss of many scrub species. The pioneer hammock community can be restored to a more diverse scrub assemblage through growing season fires to top-kill the oaks (USFWS 1998).

If a scrub community is cleared, as for agriculture, and then abandoned, a "pioneer scrub" may develop. This community is characterized by the most invasive weed and scrub species, and may become dominated by oaks. It is unknown if such a site can be restored to a high-quality F lorida scrub community (USFWS 1998).

\section{Physiognomy and Structure}

The F lorida scrub community is easy to recognize throughout its range because the shrub layer is usual ly composed of the same few species (seeBiol ogical Composition, below). The shrub layer may be dominated by oak species, or may consist of nearly pure stands of rosemary. Sand pine may occur in dense stands, as scattered 
individuals, or may be absent altogether; sometimes it is replaced by slash pine (Pinus elliottii; Myers 1990). Community structure can vary following disturbance by fire or harvesting. On more productive sites that have not burned for several decades, a well-defined layer of litter and duff usually occurs. Bare patches of sand are common and the ground cover is generally sparse. Ground cover density is often inversely proportional to the density of sand pine and shrubs (Myers 1990).

\section{Commonly Associated Plant Communities}

Florida scrub occurs in close association with longleaf pine-turkey oak sandhills, scrubby flatwoods, coastal strands, and xeric hardwood forest (FNAI and FDNR 1990). These ecosystems typically have a greater fire frequency than scrub. Once established, the fuel load and environmental conditions within each community tend to perpetuatethat community type until some disturbance or alteration in fire frequency causes the system to undergo succession.

\section{Successional Relationships}

In the complete absence of fire, scrub communities may succeed to xeric hardwoods (Christensen 1988, Myers 1990, Stout and Marion 1993). Frequent fire may lead to the disappearance of sand pine and the devel opment of an oak-dominated scrub community (Stout and Marion 1993) or a longleaf pine sandhill (Myers 1990). Figure 2 illustrates one model for the influence of fire and soil drainage on vegetation dynamics in xeric F lorida uplands (Menges and Hawkes 1998).

\section{Biological Composition}

The scrub community is composed of a relatively small number of species. The vegetation is typically dominated by a dense layer of evergreen, or nearly evergreen, shrubs. Over 90 percent of the shrub layer in Florida scrubs consists of the same six species in the same order of abundance: myrtle oak (Quercus myrtifolia), scrub oak (Q. inopina), saw pal metto, sand liveoak (Quercus geminata), Chapman's oak (Q. champanii), rusty lyonia, and Florida rosemary.

A closed or open-canopied overstory of sand pine may or may not exist (Stout and Marion 1993). Ocala sand pine (Pinus dausa var. clausa), one of the two genetic races of sand pine, has evolved serotinous cones that regenerate themselves in the harsh conditions of Florida scrub (Christensen 1988). When a fire burns this 
community, nutrients (particularly phosphorus) previously tied up in the biomass are released and quickly taken up by new seedlings in what Anderson and Menges (1997) term a "nutrient pulse." The cones remain closed on the tree until the heat of a passing fire causes them to open, thus allowing them to take advantage of the newly fertilized soil. This race of sand pine prevails in areas that are subject to fire and tends to grow in even-aged stands. The other race of sand pine, Choctawatchee sand pine (Pinus clausa var. immuginata), bears open, non-serotinous cones and does not depend on fires to reseed itself (Christensen 1988). This is an adaptation to locales unlikely to burn within one generation. These trees predominate in panhandle scrubs and in certain coastal scrubs found on peninsular Florida along the Gulf Coast where the natural fire interval was even longer than that for inland peninsular scrub. This variety of sand pine is not found on the Atlantic coast. Coastal scrub tends to be more dependent on mechanical disturbances (windthrow and washout for example) than peninsular scrub. Selection pressures in coastal ecosystems would favor trees that were more adapted to mechanical disturbance than to fire. Choctawatchee sand pines grow in uneven-aged stands as a result of their reseeding strategy. The two varieties may grow together in one stand or may form pure stands of each. When they do grow in pure stands, as many as 20 percent of the closed-cone trees may produce some open cones (Myers 1990). These trees are ensuring they will regenerate whether a fire passes through in their lifetime or not.

Bare patches of sand are common and the ground cover is generally sparse. Ground lichens (Cladonia and Cladina spp.; Myers 1990) typically dominate, but some herbaceous plants do grow on scrub soils. Depending on location, these can include: gopher apple(Licania michauxii), beakrush (Rhynchospora megal ocarpa), milk peas (Galactia spp.), beardgrass (Andropogon floridanum), and lichens (Myers 1990). The following species may also occur in the ground layer: Florida alicia (Champannia floridana), hemlock rosette grass (Panicum patentifolium), scrub balm (Dicerandra frutescens), wedge-leaved snakeroot (Eryngium cuneifolium; federally listed as endangered), Ashe's calamint (Calamintha ashei), Florida gayfeather (Liatris ohlingerae), and paper-like nailwort (Paronychia chartacea; federally listed as threatened; Stout and Marion 1993). 
Legend: $\mathrm{FF}=$ frequent fires ( $1-10$ years) years)
$\mathrm{MF}=$ moderately frequent fires (5-20

$\mathrm{NF}=$ no fires within 100 years

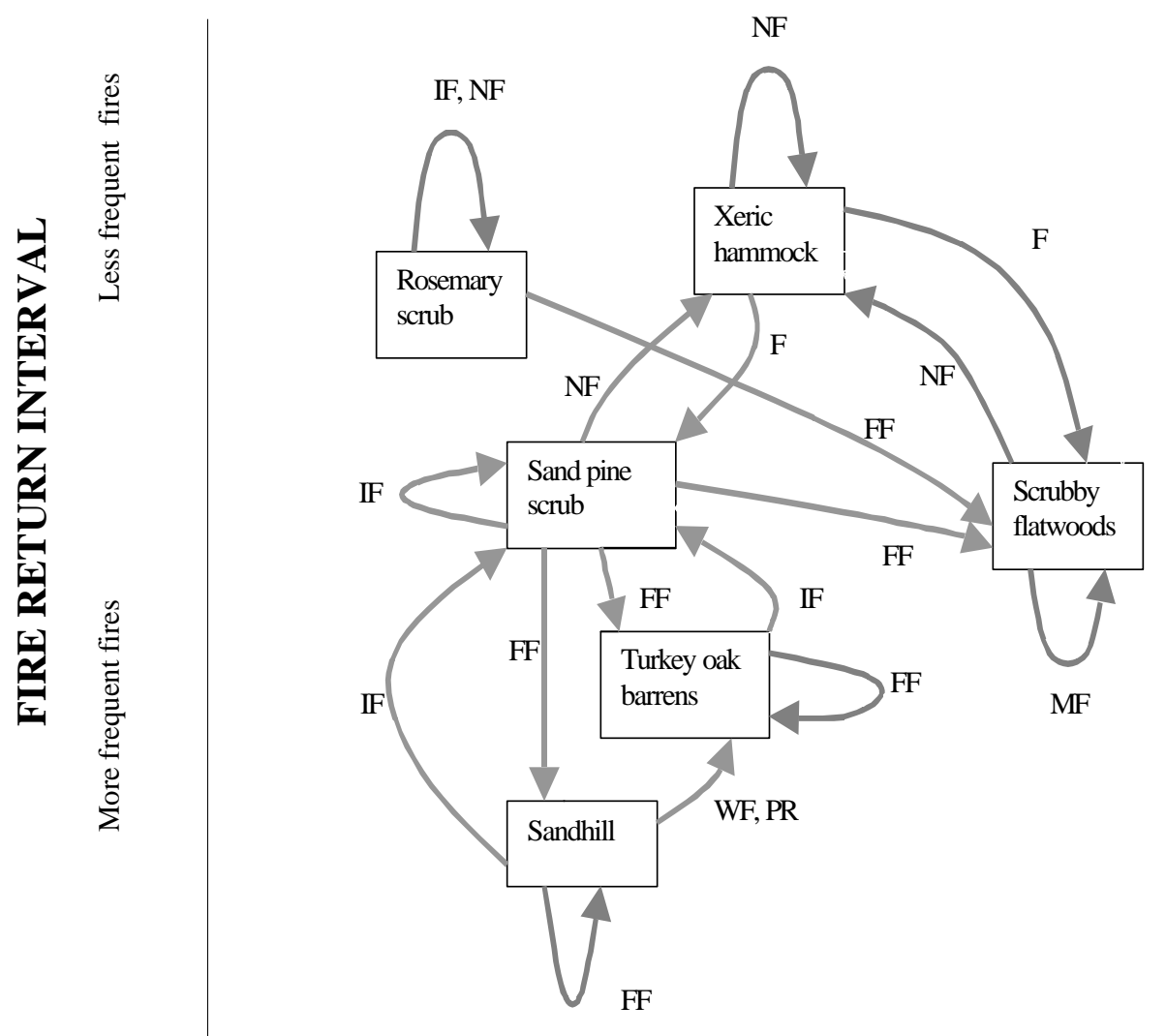

Excessively well-drained

Moderately well-drained

\section{SOIL DRAINAGE}

Figure 2. A model for the influence of fire and soil drainage on vegetation dynamics in xeric Florida landscapes. Arrows indicate hypothesized transitions between communities under indicated fire. These transitions do not alter the soil drainage characteristics at the site. (Figure courtesy of the Ecological Society of America.)
$\mathrm{WF}=$ winter fires
$\mathrm{PR}=$ pine removal
$\mathrm{F} \quad=$ fire reintroduced regime 


\section{Ecological Quality}

\section{Biodiversity and TES}

Because few plant species can grow under the conditions in which Florida scrub flourishes, Florida scrub may appear barren and unattractive. In actuality, scrub communities support a wide diversity of plants and animals. In fact, the rate of endemism is higher in scrub than in other communities that are often associated with thexeric, sandy soils of the region. A number of rarespecies are uniqueto this habitat. But the interactions of soil, physiography, fire, and vegetation that characterizescrub makethis unique community more susceptibletohuman-related disturbance and development than some neighboring communities. Sites supporting Florida scrub are easily cleared and converted to prime real estate for the devel opment of residential, commercial, and agricultural enterprises. Coastal scrub is highly susceptible to destruction in favor of beach front property development.

Florida scrub communities are known for their unique species. About 300 native plant taxa have been collected from Florida scrubs (Richardson 1989), many of which (10 to 40 percent, depending on how scrub is delineated) are not found in other habitats (Myers 1990). At least 13 federally listed endangered or threatened scrub plants, and 22 state listed plants occur on these remnant scrub patches throughout Florida (Myers 1990). Thirteen federally threatened, endangered, candidate, and SOC plant taxa occur in Florida scrub communities on DoD installations (Table 2).

Florida scrub is also home to a variety of invertebrates, a number of which have only recently been identified (M. Deyrup, $14 \mathrm{~J}$ anuary 1998). Many insects are endemic to xeric scrub communities. Many are flightless grasshoppers and beetles that are limited in range because they have poor mechanisms of dispersal. These includethescrubanomala (Anomal a eximia), Florida deepdigger scarab (Pel totrupes profundus Howden), Florida hypolichia (Hypol ichia sissipes LeConte), and theSand pine scrub ataenius (Ataenius saramari Cartwright) (Deyrup and Franz 1994). Little is known about the basic biology and ecology of these species, and they have not been listed by theState of Florida or theUSF WS due to this lack of information. 
According to Deyrup (14 J anuary 1998) there are probably other species living in this habitat

Table 2. Federally listed threatened, endangered, species of concern, and candidate plant species, and species of concern occurring in Florida scrub on installations in the southeast region.

\begin{tabular}{|c|c|c|c|c|}
\hline Common Name & Scientific Name & Installation & $\begin{array}{l}\text { Federal } \\
\text { Status }\end{array}$ & Habitat/Community \\
\hline \multicolumn{5}{|l|}{ Woody Plants } \\
\hline $\begin{array}{l}\text { Jointweed, } \\
\text { Large-leaved }\end{array}$ & $\begin{array}{l}\text { Polygonella } \\
\text { macrophylla }\end{array}$ & $\begin{array}{l}\text { Eglin AFB, FL } \\
\text { Tyndall AFB, FL } \\
\text { NAS Pensacola } \\
\text { and Outlying } \\
\text { Bronson Field }\end{array}$ & SOC & $\begin{array}{l}\text { In sand pine forests in natural openings in the } \\
\text { canopy, or along paths or powerline rights of way. } \\
\text { Occasionally observed in disturbances in } \\
\text { sandhills (Johnson 1993) }\end{array}$ \\
\hline $\begin{array}{l}\text { Lupine, Gulf } \\
\text { Coast }\end{array}$ & Lupinus westianus & Tyndall AFB, FL & SOC & $\begin{array}{l}\text { Coastal scrubs and dunes, disturbed habitats } \\
\text { (FNAI 1994a). A gulf coast dune plant, it } \\
\text { occupies exposed and active sand dunes facing } \\
\text { the Gulf and occasionally disturbed areas where } \\
\text { construction has removed the native vegetation } \\
\text { (Ward 1979) }\end{array}$ \\
\hline \multicolumn{5}{|l|}{ Forbs } \\
\hline $\begin{array}{l}\text { Aster, } \\
\text { Godfrey's Golden }\end{array}$ & $\begin{array}{l}\text { Chrysopsis } \\
\text { godfreyi }\end{array}$ & Tyndall AFB, FL & SOC & $\begin{array}{l}\text { Sunny openings in scrub, also on dunes and } \\
\text { backdunes (FNAI 1994a) }\end{array}$ \\
\hline Eulophia & $\begin{array}{l}\text { Pteroglossaspis } \\
\text { ecristata }\end{array}$ & $\begin{array}{l}\text { Avon Park AFB, } \\
\text { FL } \\
\text { Camp Blanding, } \\
\text { FL }\end{array}$ & SOC & $\begin{array}{l}\text { Tolerates a wide range of moisture conditions, } \\
\text { from very xeric to seasonally inundated or almost } \\
\text { permanently saturated soils, but most records are } \\
\text { from sites that dry out, at least seasonally. } \\
\text { Scrub, sandhills, flatwoods, various natural and } \\
\text { human-disturbed open areas (Russo et al. 1993) }\end{array}$ \\
\hline Milkweed, Curtiss & Asclepias curtissii & Avon Park, FL & SOC & $\begin{array}{l}\text { Endemic to scrub. Plants almost never grow } \\
\text { close together, so several acres of scrub may } \\
\text { only have a few widely scattered plants (Ward } \\
1979)\end{array}$ \\
\hline Pigeon Wings & Clitoria fragrans & Avon Park, FL & $\mathrm{T}$ & $\begin{array}{l}\text { Scrub and habitats intermediate between scrub } \\
\text { and sandhills (turkey oak barrens; Christman and } \\
\text { Judd 1990) }\end{array}$ \\
\hline
\end{tabular}

* $\mathrm{SOC}=$ Species of Concern, $\mathrm{T}=$ Threatened, $\mathrm{E}=$ Endangered . 
Table 2. Federally listed threatened, endangered, species of concern, and candidate plant species, and species of concern occurring in Florida scrub on installations in the southeast region.

Wireweed

Polygonella

basiramia
Avon Park, FL E

Restricted to sand pine-evergreen oak scrub, a species of early scrub vegetation development.

Grows in areas of bare sand within sand pine and

Florida rosemary (Howie 1994). Ubiquitous in

firebreaks, trails and other disturbed areas

(USFWS 1995) 


\begin{tabular}{|c|c|c|c|c|}
\hline \multicolumn{5}{|c|}{ Grasses, Rushes, and Sedges } \\
\hline Bluestem, Scrub & $\begin{array}{l}\text { Schizachyrium } \\
\text { niveum }\end{array}$ & Avon Park, FL & SOC & $\begin{array}{l}\text { Found only in white sand scrubs, a rarer scrub } \\
\text { endemic (Christman and Judd 1990) }\end{array}$ \\
\hline \multicolumn{5}{|l|}{ Non-vascular } \\
\hline $\begin{array}{l}\text { Cladonia, Florida } \\
\text { Perforate }\end{array}$ & Cladonia perforata & Eglin AFB, FL & $E$ & $\begin{array}{l}\text { Inhabits sunny, bare sand in scrub vegetation, } \\
\text { often near rosemary bushes (USFWS 1995) }\end{array}$ \\
\hline
\end{tabular}

that have yet to be discovered by science. However, few people are currently looking for new species of invertebrates and many species will not be identified beforetheir restricted habitat disappears. The problem is illustrated by thehistory of the Highlands scrub tiger beetle (Cicindela highlandensis), which is known from only two scrubs on the Lake Wales Ridge; both sites have recently been destroyed by land development.

Florida scrub is also home to many vertebrate species, including a number of wideranging, widely distributed mammals. Black bear (Ursus americanus), white-tailed deer (Odocoileus virginianus), bobcat (F elis rufus), gray fox (U rocyon cineroargenteus), and raccoon (Procyon lotor) all use scrub from time to time (Myers 1990). Many avian species will also use scrub if the canopy remains sparse. These include: common nighthawk (Chordeiles minor), common ground dove (Columbina passerina), northern bobwhite quail (Colinus virginianus), loggerhead shrike (Lanius ludovicianus), and palm warbler (Denroica palmarum), all of which prefer areas of low, open vegetation.

When a sand pine overstory develops, different species are attracted to scrub (reviewed in Myers 1990). Flying squirrel (Glaucomys volans), grey squirrel (Sciurus carolinensis), golden mouse (Peromyscus nuttali), and cotton mouse ( $P$. gossypinus) are examples of mammals that prefer a moreclosed canopy. Red bellied woodpeckers (Melanerpes carolinus) and downy and hairy woodpeckers (Picoides pubescens, P. villosus), will also use this habitat when there is sufficient pine stem density. Other avians includegreat crested flycatcher (Myiarchus crinitus), bluejay (Cyanocitta cristata), Carolina wren (Thryothorus ludovicianus), pine warbler (Dendroica pinus), mourning dove (Zenaida macroura), eastern screech owl (Otus saio), Cooper's hawk (Accipiter cooperii), as well as wintering wood warblers (Parulinae sp.), blue-grey gnatcatchers (Polioptila caerulea), and solitary vireos (Vireo solidarius). 
Approximately 70 species of vertebrates have been collected in scrub habitats; some of them are not known to occur elsewhere (reviewed in McCoy and Mushinsky 1994). TES that are found in scrub on DoD lands include: the Florida mouse (Podomys floridanus) and the F Iorida scrub lizard (Scel opor us woodi), both species of special concern in Florida; the Florida scrub jay (Aphelocoma coerulescens, federally listed as threatened), the sand skink (Neoseps reynol dsi, federally listed as threatened), and the blue-tailed mole skink (E umeces egregius lividus, federally listed as threatened). Many of these vertebrate TES can be found on DoD Iand (Table 3). Some federally listed endangered species are found on only one protected scrub site, and a few have no formal protection at all (Myers 1990).

Table 3. Vertebrate species Federally and State listed, occurring in Florida scrub on installations in the southeastern United States.

\begin{tabular}{|c|c|c|c|c|}
\hline Common name & Scientific name & $\begin{array}{l}\text { Federal } \\
\text { Status }^{*}\end{array}$ & $\begin{array}{l}\text { State } \\
\text { Status }\end{array}$ & Installation Name(s) \\
\hline \multicolumn{5}{|l|}{ Reptiles } \\
\hline Gopher Tortoise & Gopherus polyphemus & FT & ST & $\begin{array}{l}\text { Avon Park AFR } \\
\text { Cape Canaveral Air Station } \\
\text { Camp Blanding } \\
\text { Eglin AFB } \\
\text { NAS Whiting Field } \\
\text { Pensacola Air Station } \\
\text { Tyndall AFB }\end{array}$ \\
\hline Florida Scrub Lizard & Sceloporus woodi & $N$ & SSC & Avon Park AFR \\
\hline Eastern Indigo Snake & Drymarchon corais couperi & FT & ST & $\begin{array}{l}\text { Avon Park AFR } \\
\text { Cape Canaveral Air Station } \\
\text { Camp Blanding } \\
\text { Eglin AFB }\end{array}$ \\
\hline Florida pine snake & Pitophis melanoleucus mugitus & $N$ & SSC & $\begin{array}{l}\text { Camp Blanding } \\
\text { Eglin AFB } \\
\text { Avon Park AFR }\end{array}$ \\
\hline Sand Skink & Neoceps reynoldsi & FT & ST & Avon Park AFR \\
\hline Blue-tailed Mole Skink & Eumeces egregius lividus & FT & ST & Avon Park AFR \\
\hline
\end{tabular}

Federal Rankings: FE = Endangered; FT = Threatened; C = Candidate Species (former C1 species); SAR = Species at Risk (former C2/C3 species); $\mathrm{N}=$ None

State Rankings for Florida: SE = Endangered in the State; ST = Threatened in the State;

$\mathrm{SSC}=$ Species of Special Concern in Florida; $\mathrm{N}=$ None 


\begin{tabular}{|c|c|c|c|c|}
\hline \multicolumn{5}{|l|}{ Mammals } \\
\hline $\begin{array}{l}\text { Florida Long-tailed } \\
\text { Weasel }\end{array}$ & Mustela frenata peninsulae & C & & Avon Park AFR \\
\hline Florida Mouse & Podomys floridanus & $\mathrm{N}$ & SSC & $\begin{array}{l}\text { Cape Canaveral Air Station } \\
\text { Camp Blanding } \\
\text { Avon Park AFR }\end{array}$ \\
\hline \multicolumn{5}{|l|}{ Amphibians } \\
\hline Gopher Frog & Rana capito & $N$ & SSC & $\begin{array}{l}\text { Eglin AFB } \\
\text { Camp Blanding } \\
\text { Avon Park AFR }\end{array}$ \\
\hline \multicolumn{5}{|l|}{ Birds } \\
\hline Florida Scrub Jay & $\begin{array}{l}\text { Aphelocoma coerulescens } \\
\text { coerulescens }\end{array}$ & FT & ST & $\begin{array}{l}\text { Avon Park AFR } \\
\text { Cape Canaveral Air Station } \\
\text { Camp Blanding }\end{array}$ \\
\hline $\begin{array}{l}\text { Red Cockaded } \\
\text { Woodpecker }\end{array}$ & Picoides borealis & FE & & Avon Park AFR \\
\hline $\begin{array}{l}\text { Southeastern } \\
\text { American Kestrel }\end{array}$ & $\begin{array}{l}\text { Falco sparverius } \\
\text { paulus }\end{array}$ & soc & ST & Avon Park AFR \\
\hline
\end{tabular}

\section{The Use of a Community Quality Assessment}

To practice sound ecosystem management, several policy goals must be reconciled: the military mission, protection of TES, and consumptive land uses such as production of forest commodities. Decisions regarding land use priorities can be guided by site classification on the basis of ecological quality. Site quality initially can be assigned using baseline data, but should be augmented by a monitoring program that evaluates the effects of land use decisions. Determination of community quality has obvious benefits for TES conservation planning. Low quality communities do not provide the same habitat quality for TES as higher quality communities, and therefore should be treated differently in terms of protection, restoration efforts, and allowable land uses. Use of a quality ranking system for management purposes can assure that protection priority is given to highest quality TES habitat. Furthermore, use of this system can assure that restoration activities are used for communities that have the potential to become high quality TES habitat with minimum restoration efforts. Similarly, use of a quality ranking system can ensure that efforts are not wasted in the restoration of low quality communities. Finally, plant communities on installations are subject 
to multiple land uses, and use of a quality ranking system in combination with an assessment of impacts of various land uses can allow managers to determine which activities are appropriate in which communities, based on the potential to provide quality habitat for TES. The ranking system developed for Eglin AFB, FL, using "Type" categories to denote ecological quality, was introduced in the companion document by Harper et al. (1997) and has been adapted for this report as well (more information can befound in Appendix G). Management recommendations found in this document are oriented towards the highest quality sites on military installations, unless specifically noted otherwise.

\section{Indicators of Community Quality}

Indicator Species. The presence or absence of some plant species is considered to indicate degradation. These indicators have been noted for Florida scrub:

1. The exotic species, cogon grass (I mperata cyl indrica), may become common in degraded scrubs. This is an aggressive, invasive species and can out-compete the native vegetation. It is more likely to invade following silvicultural activities and other disturbances, because propagules can be dispersed on vehicles (Doria Gordon, State Ecologist for the Florida region of The Nature Conservancy, professional discussion, 5 February 1996 [hereafter referred to as D. Gordon, 5 February 1996]). However, the increased prevalence of viable seed now devel oping in F lorida suggests that even undisturbed scrubs may be increasingly susceptibleto invasion. Cogon grass is detrimental to all natural communities, not just scrub, and its presence should indicate a priority for intervening management.

2. Florida scrub jays can be used as indicator species for healthy, natural scrubs. The scrub jay is a federally threatened endemic species that is found on a number of military installations in the peninsular portion of Florida. These include Avon Park AFR, NAS J acksonville, Camp Blanding, and Cape Canaveral Air Station. High-quality, oak-dominated scrub is the preferred habitat for scrub jays. They favor areas with thickets of scrub oaks 1 to $3 \mathrm{~m}$ in height with less than 50 percent canopy cover interspersed with bare patches of sand (USFWS 1990b). Optimal scrub jay habitat occurs in areas with the foll lowing structure: (Wool fenden, 1974; Cox, 1984; Wool fenden and Fitzpatrick, 1984, 1991; Bereininger, 1992; Bereininger et al. 1995; Duncan et al. 1995)

! 10 to 30 percent of the patch is composed of bare sand or sparse herbaceous vegetation 
! more than 50 percent the shrub layer is made up of oaks

! shrub height is between 1.2 and $1.7 \mathrm{~m}$

! pine canopy cover is less than 15 percent

! distance from a forest is greater than $100 \mathrm{~m}$.

Their preferred habitat can be used as a management goal for some, but not all portions of a managed scrub. Although these criteria also indicate high-quality habitat for other vertebrateTES (e.g., Florida scrub lizards), an entire scrub should not bemanaged totarget these parameters, because habitat requirements for other scrub species may be different from those of scrub jays (Christman 1995). For example, sand skinks are widely dispursed in xeric uplands. They prefer areas free from abundant plant roots with open canopies, scattered shrubby vegetation, and patches of bare sand (USFWS 1998), similar to the habitat prefered by jays. Mushinsky and McCoy (1995) showed, however, a negative correlation between the abundances of Florida scrub jays and sand skinks. Thereasons for this relationship remain unknown. There is little evidence that scrub jays prey on sand skinks (USFWS 1998). It may be due to ecological interactions between the two species or imperceptible differences in xeric habitat that favors one species over another, but this relationship illustrates that maintaining habitat for one species may be incompatable with the habitat requirements of another.

Christman (1995) suggested that scrubs at Camp Blanding are probably in need of management when more than 50 percent of the scrub area that could potentially support scrub jays has become unsuitable due to changes in structure since the last fire, but the requirements of all species living there should be taken into consideration.

High-Quality Examples. Physiognomic structure in fire-maintained, even-aged scrub will vary markedly with time since last fire, because fire is catastrophic to this community. Structure also varies depending on whether or not the scrub has sand pine in the canopy. Structure in natural Florida scrubs probably was not homogeneous, because natural fires did not burn scrub all at once, but created a mosaic of patches having been burned last at different times. I mmediately after burning, scrubs will bewithout living, above-ground vegetation, but beforethenext fire, they will be composed of densely stocked oaks, 2 to $4 \mathrm{~m}$ tall (Christman 1995). Christman noted that there is no single way scrub should appear, and there is no single fire return interval that can be applied to all scrubs. Differences between high and low quality scrubs may have more to do with activities such as logging and recreational impacts than fire suppression. Two examples of high-quality scrubs have been provided. 
! The Florida Natural Areas Inventory (1994b) described a high-quality, uneven-aged coastal Florida scrub at Eglin AFB, in which the canopy consisted largely of sand pine, with occasional sand live oak, live oak (Quercus virginiana), and sand hickory (Carya pallida). Cover ranged from 5 to 25 percent. The midstory was typically a dense, patchily distributed mix of evergreen broad-leaved small trees and tall shrubs $(>2$ $\mathrm{m})$. Heights varied, giving a multilayered appearance. Cover of tall shrubs was typically 5 to 25 percent, while that of short shrubs $(<2 \mathrm{~m})$ was between 50 and 75 percent. Herbaceous plants in the ground cover were very sparse, typically less than 5 percent cover. A dense cover of reindeer lichen (Cladonia spp.) was commonly found, and leaf litter may have become thick if vegetation was dense. Abundant bare sand occurred between patches of vegetation. There was little to no evidence of anthropogenic disturbance (few to no very old tree stumps, little disturbance to soil, especially away from roads). Windthrows of sand pine were evident. Weedy species were rare or absent.

! Although every scrub is different, thefollowing was described by FNAI and TNC (1995) as what an ideal scrub community should look like: An ideal high-quality site may have a sparse to moderately dense canopy of mature sand pine. Absence of sand pine does not rule out classification as a [high-quality site], but may influence other factors within the site. Open sandy areas that are created by windthrown sand pine contribute to an increased diversity of herbs as well as habitat for scrub jays... The shrub component, dominated by scrub live oak ... and rusty lyonia ... may be of variable density, but at least $10 \%$ coverage of open sand is desirable. The height of the shrub layer rarely exceeds $3 \mathrm{~m}$ within a [high-quality] site and generally is less than $2 \mathrm{~m}$. Shrub height should be between 1 and $3 \mathrm{~m}$ tall. Herbaceous plants are very sparse, typically less than $5 \%$ coverage. A dense cover of lichens is commonly found, and leaf litter may also be thick. There is little or no evidence of ground disturbance within the site... Firebreaks should never be present between the scrub and the adjacent natural communities... Soil disturbances including firebreaks cover less than $5 \%$ of the area. Weedy species are rare or absent.

Degraded Examples. Degraded examples of coastal Florida scrub (Intermediate quality sites) were provided for coastal scrub at Eglin AFB, FL (FNAI 1994b). Composition and structure were similar to the high-quality scrub on Egl in AFB (see 
High-Quality Examples), but the areas had been subjected to timber removal, so that no old sand pine persisted in the canopy. Evidence of logging was present.

Degraded examples of F lorida scrub (Intermediate quality sites) were provided for communities at Camp Blanding, FL (FNAI and TNC 1995). Firebreaks, roads, and an old motor-cross track disturbed the ground. Sites with an average shrub layer height greater than $3 \mathrm{~m}$ or with soil disturbance covering more than 5 percent of the site should be classified as intermediate quality.

Fire suppression allows some of the oaks to attain tree size. If they produce a great deal of shade or capture a majority of the resources of the site, the commuinty will lose its less competitive components, and overall, support fewer species than the original scrub or a typical hammock community. The native scrub can be restored through growing season fires (USFWS 1998). 


\section{Land-Use Practices and Activities}

Many remaining scrub communities have been degraded by past management practices, land uses, or other anthropogenic disturbances and are only intermediate to moderate in quality. Also, many scrubs currently are subjected to multiple land uses. This section is intended to provide an overview of the management practices and multiple land uses to which scrubs on military installations may be subjected. Major activities in Florida scrub are discussed below.

\section{Fire Management}

Many communities in the Southeast, including the closely associated scrub, sandhill, and longl eaf pine communities are said to be pyrogenic because they have historically been maintained by fire. However, most of Florida's woodlands came under effective fire suppression between 1920 and 1950. The U.S. Forest Service, timber farmers, and other land owners saw wild fires as a threat to woodlands and began to suppress all fires that broke out within these communities. This policy lead to changes in the landscapeand the development of denseforests in someareas (Frost 1993). Because it is not unusual for the interval between fires to be 30 years or longer, some scrubs have not undergone major changes as a result of the recent fire suppression policy in Florida, and the integrity of these areas persists. In other areas however, fire suppression in scrub communities has caused a change in the biotic component and character of those scrubs. In the absence of fire, the shrub community and sand pine overstory will mature, shading out herbaceous ground cover. The bare patches of sand that are common in scrub begin to disappear as young oaks invade. In the total absence of fire, these areas will develop into a xeric hardwood forest (Myers 1990).

Even after fire suppression became the rule in other parts of Florida, frequent fire continued to occur throughout the year on military installations in artillery impact areas, with occasional accidental or prescribed fires affecting other areas. As a means of fire suppression and to control prescribed fires, managers have created plow-lines and roads throughout natural communities. Creating plow-lines involves removing vegetation to the mineral soil layer. Historically, plow-lines were often placed along ecotones between neighboring communities (Frost et al. 1986). 
Current fire management practices in scrub are discussed el sewhere (see I mpacts and Management Recommendations, Fire/Fire Suppression). Current practices indude the use of prescribed fire, plow-lines, and other methods to control the spread of fire (e.g., use of surfactant foams and natural wetland barriers).

\section{Agricultural and Forestry Practices}

Current land use practices for scrub in the state of Florida include clearing for pasture land and citrus production. (Although these practices do not occur on DoD lands, we mention them here because it may be hel pful when looking at scrub in the context of past land use practices and conversion to other land use types). Even before these agricultural disturbances threatened existing scrub, this community was rare. Today, citrus farmers and ranchers have accelerated conversion to these new land uses because they fear impending governmental restrictions on the use of their scrublands. Some farmers and land owners have cleared their lands only to let them sit idle for years afterward. A patch of scrub near J osephine Creek in Highlands county was cleared by the landowner for this reason (Myers 1990). Commercial agricultureis clearly incompatible with TES conservation in scrub, and may increase the burden of TES management on federal and state land managers.

Some forestry practices have also occurred in scrub. According to Christensen (1988), historical accounts suggest that longleaf pine once grew in many areas that are scrub today. Longleaf pines served as an important source of turpentine. Scars from this enterprise can still be seen on some of the relict pines in these areas. These trees were generally misshapen under their natural growing conditions and were not suitable for saw timber. Most harvesting was done for tar extraction. This action, in turn changed the fire regime, allowing hardwoods to invade. Eventually, sand pinetook over as the dominant pine in the ecosystem and longleaf pine has been slow to reinvade (Christensen 1988). Today, sand pine is a commercial timber species. The U.S. Forest Service allows commercial harvesting of sand pine to occur on federal lands in the Ocala National Forest. Harvesting is followed by re-planting sand pine on Forest Servicelands (Laura L owery, Biologist, U.S. Forest Service, Ocala National Forest, professional discussion, 25 February, 1998) but the case may not be the same on private lands.

\section{Development}

Human encroachment and development of scrub has been heavy, due to a burgeoning human population in Florida. This population explosion continues to 
place more and more pressure on natural habitats. In 1960 the population in Florida was 4.95 million (Terhune 1982). Twenty years later it nearly doubled to 9.75 million people (Terhune 1982). In 1994 the Florida Department of Commerce estimated the number to be 13.9 million and projected that figure could increase to 15.5 million by the end of this century (Mitchell 1997). Florida could haveas many as 18 million people by the year 2010 (Florida Department of Commerce 1998). The demand for housing has escalated similarly over the past 40 years. Businesses creating goods and services for the growing population have al so flourished as they encroach even further into natural communities. Scrubtypically occupies the areas of high-value real estate that are in demand by Florida's developers. Most of the housing developments located in former scrub habitat are less than 20 years old (USFWS 1990b). The sites that are most likely to disappear in the foreseeable future are located in the heavily developed areas of Bravard, Highlands, and Palm Beach counties (USFWS 1990b). Fragments of Florida scrub persist on military installations because they are protected from much of this development. 


\section{Impacts and Management Recommendations}

Management information is based on literature review, contacts with experts, and guidelines provided in installation reports. Information on habitats and management for rare plant and animal species was gathered from USFWS Recovery Plans, TNC E lement Stewardship Abstracts, J ordan et al . (1995), Godfrey and Wooten (1979, 1981), Kral (1983), Small (1972), and Ward (1979).

\section{Fragmentation and Land-Use Conversion}

\section{Impacts}

Across Florida, many scrub communities have been fragmented and converted for residential devel opments or citrus production (Christman and J udd 1990). Natural communities on DoD installations also are fragmented by systems of roads, firebreaks, sometimes by drop zones, and facilities construction. Thegeneral effects of fragmentation on TES populations include outright habitat loss, population isolation, changes in plant and animal assemblages through altered competition, and changes in predation, parasitism, and herbivory patterns (reviewed in general by Trame and Tazik 1995).

Fragmentation can also result in localized extinctions of flora and fauna more often than in contiguous habitat, if species' dispersal rates or mechanisms do not allow them to emigrate between habitat patches. The effects of patch size, patch isolation (distance to nearest neighbor patch), and presence of connecting xeric habitat ("corridors") on species richness for several taxonomic groups was studied for peninsular, inland sand pinescrub communities (McCoy and Mushinsky 1994). The size of a scrub fragment (ranging from 1.5 ha to $190 \mathrm{ha}$ ) was positively correlated with adjacency to certain types of upland habitats and more types of habitat in the adjacent landscape, and negatively correlated with adjacency to disturbed or converted land and decreases in patch size over the past 50 years. Any effects of patch size could have been influenced by these factors. Larger patches of scrub were strongly correlated with high species richness of nonavian taxa, 
"characteristic" (typical of scrub communities) nonavian taxa, breeding birds, and characteristic avian taxa. The presence of rosemary was also more likely in larger scrubs (McCoy and Mushinsky 1994). Another study found the occurrence of 16 Florida scrub plant species in inland rosemary scrub to be correlated with a combination of or the interaction between increasing patch size (range: 0.03 to 3.6 ha) and decreasing patch isolation (Quintana-Ascencio and Menges 1996).

Nonetheless, there is evidence that even small patches of inland scrub can support characteristic plant and vertebrate diversity. Qunitana-Ascencio and Menges (1996) found that 31 out of 62 species were no less likely to be found in smaller patches or more isolated patches, even when the interaction with fire history was considered. McCoy and Mushinsky's (1994) vertebrate study found that the three largest study patches, each cl oseto 200 ha in size, did not contain more species than combined groups of small patches of equal total area. Conservation of a few large scrub remnants may not be more valuable than maintaining many relatively small patches on the landscape, at least for the measures studied to date. In fact, scrubs of less than 50 ha supported relatively more species than expected, while scrubs of 150 to 200 ha supported fewer species than expected. This trend was consistent for threatened and endangered fauna as well as rare amphibian and reptiles (McCoy and Mushinsky 1994).

The requirements of specific listed species are needed in order to manage with an emphasis on conserving TES. It is known that the state threatened short-tailed snake (Stil osoma extenuatum Brown) is able to survive in fragments as small as an acre, as long as the habitat is not too degraded (Campbell 1992). This snake appears to beable to co-exist with human activities as long as the invertebrates and small vertebrates upon which it preys persist. This type of information is needed for many more listed plants and animals.

Highly fragmented communities are a threat to species that rely on frequent colonization from source populations (e.g., Bachman's sparrows; Dunning 1993). Florida scrub lizards were shown by Hokit, Stith, and Branch (In Press) to be absent from 89 of the 132 patches of scrub they surveyed on Avon Park AFR and the nearby Arbuckle State Forest from 1994 through 1996. Through the use of multivariate habitat modeling techniques, they determined that patch size and patch isolation were the only two variables that explained the scrub lizards' distribution. Thesereptiles exhibit poor dispersal capabilities and do not move well through dense habitat. Because of the relatively high degree of patch isolation, they are unable to col onize suitable habitat. 
Isolated habitat patches can be problematic for species with large home ranges, especially if they are slow-moving or conspicuous, or if individuals become vulnerable during dispersal movements. Such is the case with the gopher tortoise (Lohoefener and Lohmeier 1981). These tortoises live in a naturally discontinuous habitat. Scrub and sandhills are often bisected and surrounded by wet boggy areas that may serve as impediments to adult male courtship movement. This problem has been exacerbated by the encroachment and further fragmentation of the habitat by human activities. Alford (1980) observed that tortoise colonies tend to be of the same age class, which implies that gopher tortoises do not have high rates of inter-col ony migration. Diemer (1992) studied home range movements of gopher tortoises in northern Florida and determined the mean home range for adult males was $0.88 \mathrm{ha}$. For females, the range was $0.31 \mathrm{ha}$. She noted the longest recorded movement as $0.74 \mathrm{~km}$. The mean home range for gopher tortoises was reported by McRea, Landers, and Garner (1981) as 0.45 ha for males and 0.21 ha for females. These studies looked at movements over a relatively short period of time. Douglass (1976) monitored two male tortoises for 5 to 6 years and reported home ranges in these individuals as 4.2 and 6.3 ha, respectively. Home ranges of this size indicate that tortoises will travel sizable distances for mating purposes. Since many fragments of suitable tortoise habitat are far smaller in area than the potential home range for male tortoises, and because these patches may be considerable distances from one another, with no corridors connecting them, males residing in these small fragments may be restricted to these patches and therefore unable to attain access to new breeding females; i.e., the mature tortoises in these small patches are physically and reproductively isolated from others of breeding age. Such isolation over time can produce genetic distinction and the occurrence of some inbreeding can reasonably be assumed.

In recent years, conservation has emphasized increasing theconnectivity of existing habitat patches to combat problems associated with fragmentation. Managers practicing stewardship in a variety of natural communities have sought to use corridors to augment existing tracts of high-quality habitat. The establishment of corridors will unite areas of suitable habitat and allow individuals of a species to emigrate between patches, promoting gene flow between colonies. This strategy may or may not be appropriate for occurrences of Florida scrub; and it may or may not be appropriate for all management objectives. Sites characterized by the harsh environmental conditions that define scrub have historically been disjunct and isolated from other such patches. Those species endemic to scrub may be adapted to isolated habitat. Indeed, the presence or absence of connecting habitats was not correlated with species richness for nonavian taxa, "typical scrub"nonavian taxa, breeding birds, and typical scrub avian species (McCoy and Mushinsky 1994). The value and potential risk of corridors to specific species needs to be evaluated. 
Researchers at the University of South Florida are currently looking at the spread of upper respiratory tract disease in gopher tortoises in relationship to habitat management practices, induding the presence of corridors (Earl McCoy, Professor, Department of Biology, University of South Florida, professional discussion, 29 J une 1998). Populations can be decimated by disease spread via corridors when they would otherwise be protected from such epidemics by virtue of their segregation from other isolated populations.

In the absence of suitablecorridors, someindividuals will certainly movebeyond the boundaries of their natural habitat and through devel oped areas in search of mates or new habitat. This behavior leads to increased mortality from a variety of sources, including human activities and predators.

Humans have been the principal predator of maturetortoises, using them as a food source during the Great Depression (USFWS 1990a). This practice remains a cultural ethos in many rural areas of the United States. Collecting for the pet trade also takes a toll on gopher tortoise populations. However, tortoise eggs and hatchlings suffer the most from habitat fragmentation. For example, in southwestern Georgia, Landers, Garner, and McRae (1980) found high predation of gopher tortoise nests by skunks (Mephitis mephitis), raccoons (Procyon lotor), and crows. In Florida and Alabama, tortoises were depredated by feral dogs and cats. Young tortoises have been under predation pressure from gray fox, armadillos (Dasypus novemcintus), various species of snakes, and raptors (USFWS 1990b). Landers, Garner, and McRae (1980) al so found several hatchlings destroyed by fire ants (Solenopsis spp.). Many predators follow roads, fire breaks, and ecotones rather than searching at random when they hunt for prey. Thelikelihood of finding a prey species using this strategy increases as patch size decreases.

Since the gopher tortoise functions as a "keystone modifier" species (sensu Mills, Soule and Doak 1993) in many of the xeric plant communities of Florida, other species are affected by its dedine. Gopher tortoises dig a series of burrows through the dry, sandy soil supporting scrub, sandhill, and other xeric upland communities. Many other vertebrates use these burrows to conceal themselves from predators and to escape light, aridity, fire, and extremes in temperature, both in the summer and the winter. These include other TES, such as the gopher frog (Rana capito) and the Florida mouse, both species of special concern in Florida.

F ederally threatened eastern indigo snakes (Drymarchon corais couperi) are close burrow associates of the gopher tortoise, and as such, their population has ded ined with that of the gopher tortoise. These snakes are not restricted to scrub but can be found there when tortoises arealso present. Eastern indigo snakes have a much 
larger home range than do gopher tortoises. In Georgia, individual snakes use many tortoise burrows over a home range that can be several hundred hectares in size (USF WS 1982). These reptiles undergo long seasonal movements, sometimes several kilometers in extent. The ability to move such long distances enables indigos to establish themselves in new areas of suitable habitat. Early estimates suggested that areas need to be at least 200 ha in size (USFWS 1982); but more recently, experts suggest that indigo preserves be at least 4000 ha (USFWS 1998). An area this size could support a population of about 53 male and 210 female indigos, assuming there was total overlap of home ranges between males and females and that all of the preserve area was of suitable habitat. Because of the patchy nature of extant scrub relicts, few sites could sustain a population of indigo snakes exclusively. In most cases, indigos are forced to cross roads and highways while traveling between areas of suitable habitat. Indigos grow to be large (up to $8 \mathrm{ft}$ long), relatively slow-moving snakes (USFWS 1982). Automobile traffic accounts for a significant amount of the mortality in eastern indigo snakes as well as other species like fox squirrels, southern hognose snakes (Moler 1992, J ordan, Wheaton, and Weiher 1995) and gopher tortoises. The docile nature and conspicuousness of indigos have madethem vulnerableto collectors for the pet trade and easy targets for people who kill snakes on sight.

Another TES that has suffered the effects of habitat fragmentation is the Florida scrub jay. Unlike the gopher tortoise and eastern indigo snake, scrub jays are scrub endemics, and are therefore severely limited in habitat and range. Their threatened status is a direct result of habitat loss. Much of the high value real estate in Florida now sits on former scrub jay habitat. Coastal scrub has been deared for beachfront hotels, resorts, and housing developments. I nland scrub has been converted to citrus groves, pine plantations, and residential areas. Remaining scrub is frag-mented to the point that much of what remains is too small for a family of jays to colonize. Scrub jays use large, well-defined territories that range in size from 1 to 21 ha ( 2.5 to 52.5 acres) with a mean of 9.0 ha (22.5 acres) (Mitchell 1997). When patch size falls below a certain threshold, jays will not colonize that patch, even if it is of relatively high quality. Woolfenden and Fitzpatrick (1991) estimated the minimum threshold to be 5 ha (12.5 acres). Therefore, only large areas of scrub will sustain any significant scrub jay populations; such areas are becoming more and more scarce. Road hazards may also posea significant threat to the Florida scrubjay. These birds frequently forage by roadsides, which offer the large openings jays require for foraging. Mortality from collisions with automobiles is common (Dreschel, Smith, and Breininger 1990) and may even factor into the extirpation of small populations. 
Fragmentation can pose problems if barriers are created between upland habitats and the wetlands on which TES depend for breeding purposes. For example, amphibians like the gopher frog depend on gopher tortoiseburrows in longleaf pine, xeric hammock and Florida scrub for shelter (Godley 1992). For mating purposes, however, these frogs will disperse a mile or more to find breeding ponds, only to return to the same tortoise burrow at the end of the breeding season (Godley 1992). If fragmentation creates a barrier between the xeric habitat and the breeding ponds, amphibians, like the gopher frog, will not be able to reproduce (A. Weakley, Southeast Regional Ecol ogist, Southeast Regional Office, TheNatureConservancy, professional discussion, 12 May 1995 [hereafter referred to as A. Weakley, 12 May 1995]). A recent study using species-area relationships to determine the effects of fragmentation on richness of vertebrates in Florida scrub found that when the influence of scrub patch size was removed from the analysis, distance (both to permanent water and to the nearest scrub patch) correlated strongly with nonavian vertebrate richness (McCoy and Mushinsky 1994).

When all other factors are equal, larger areas of habitat maintain the largest numbers of TES. A large population reduces the possibility of extinction. Reproductive success and mortality rates of some TES are inextricably linked to habitat quality and may be influenced by human activities and the structural features of communities neighboring scrub. Florida scrub jay populations, for example, are negatively influenced by the proximity of forests due to increased predation by woodland hawks (Breininger et al. 1995). The location and nature of operations for the space program and national defense can affect jays living on National Aeronautics and SpaceAdministration (NASA) property at Kennedy Space Center and at Cape Canaveral Air Station (Breininger et al. 1996). Scrub jays and other TES populations may also be vulnerable to natural catastrophes, such as hurricanes or other climatic events, disease epidemics or heavy parasite infestations, especially when the colonies are small or closely packed. Therefore, populations in large, contiguous landscapes have the best chances of withstanding these pressures, ensuring their long term survival. If restoration efforts are successful, this will result in a healthier, more contiguous ecosystem and would allow for the continuation of natural processes across the landscape. Such restoration would also permit more effective management at the landscape level (e.g., landscape-level burns).

Fragmentation of a plant community that requires firecan cause problems with fire management. For example, if natural communities requiring firemanagement are within city limits or are surrounded by housing, prescribed burning may not be feasible because of smoke management problems (A. Weakley, 12 May 1995). The smoke caused by prescribed firemay drift across nearby highways or landing strips, 
causing visibility problems for drivers and pilots, or may blow intoresidential areas, where it may pose health problems for the elderly and others with respiratory difficulties. The possibility of prescribed fire jumping fire breaks is also a dilemma for managers due to the high-intensity nature of fire in Florida scrub. Such fires are extremely difficult to control. The danger of fire escaping when the burn area is in close proximity to residential areas, munitions depots, or other developed real estate must be considered when using fire to manage small patches of scrub.

\section{Management Recommendations}

The creation of large patches of scrub habitat should be the focus of Florida scrub restoration activities. Florida managers should attempt to restore those degraded areas that are adjacent to areas of high-quality habitat even, if these areas cannot connect two larger patches. Depending on the species being managed, corridors may or may not be desirable. Regardless of whether tracts are being connected or not, blocks of habitat should be as round as possible. This will further minimize edge effects on TES populations.

At the same time, further fragmentation of natural communities should beavoided whenever possible. Scrub communities have already suffered fragmentation by manmade fire breaks and roads. Myers (1990) states that many of the rarer scrub endemics seem to proliferate in fire plow-lines, permanent fire breaks, and other areas that have been mechanically disturbed. Fire lines that divide a larger burn unit into several smaller ones for purposes of fire management could be left to mimic the natural discontinuity of scrub habitat (see mechanical disturbances section under recommendations regarding fire). However, ecotones should never be disturbed if natural systems management is a goal. Fire breaks constructed through these transitional zones only exacerbate fragmentation issues. Existing roads and plow-lines that run along natural ecotones should be abandoned and the ecotones allowed to recover with natural vegetation. Fire ditches should be filled with the appropriate soil and restored to the original grade (Christman 1995).

If natural areas must be cleared or developed, these activities should be concentrated in one area, preferably adjacent to areas that have already been developed, and not spread throughout natural communities. This will minimize edge effects caused by fragmentation. Activities that will interrupt TES population processes, or ecosystem processes, should be avoided, or an alternative location for the activity should be sought. For example, avoid fragmentation activities such as road building, that will create barriers between connected habitats used by a species. 


\section{Fire and Fire Suppression}

Historically, fires resulting from lightning strikes occurred frequently in the southeast, burning longleaf pine communities during the growing season (Abrahamson and Hartnett 1990). When conditions were right, fires in longleaf pine communities were able to ignite adjacent Florida scrubs. Before current fire suppression policies were enacted, and scrub habitats became fragmented by human activities, fires spread naturally, sometimes burning areas the size of several counties (Means and Grow 1985).

Around 1920, the United States F orest Service began promoting activesuppression of wildfires; this practice continued until recently (Frost 1993). This had drastic effects on vegetation and community structure in longleaf pine communities. Fire suppression in most inland F lorida scrub communities has not been as detrimental as it has been in adjacent sandhills, because scrub has a naturally long fire return interval (estimates of 15 to 100 years) and fires are difficult to ignite (Myers 1990). But many inland scrubs are in need of burning. Human encroachment has limited the possibility of returning a completely natural fire regime to this ecosystem. The potential consequences of allowing naturally ignited wildfires to burn unchecked and unattended limit a "let-burn" response to wildfires in these areas. Long term persistence of Florida scrub will require controlled burning and/or an acceptable mechanical alternative to fire.

\section{Impacts}

Inland F lorida sand pine-dominated scrubs generally are dominated by serotinous sand pine and are firestructured communities. Coastal Florida sand pinedominated scrubs are dominated by non-serotinous sand pine (Myers 1990); these communities may not be fire-structured. The following discussion relates to firestructured scrub communities, with or without a canopy of sand pine.

Both long-term fire suppression, and fires that occur too frequently, can changethe structure and composition of the community. Long-term fire suppression may result in succession to xeric hammock, as oaks dominate over sand pine. Fires that occur too frequently will prevent the regeneration of sand pine. Some scrubby flatwoods sites occurring in Florida today are a result of clearcutting sand pine and burning so frequently that sand pine was unable to reseed. Though the species is termed "fire resistant," fire in sand pine communities will kill individual trees. Sand pine regenerates profusely foll lowing fire when the serotinous cones open and release their seeds. New individuals can produce cones in as early as 5 years and may live to be 100 years old. In the absence of fire, stands typically begin to break 
up after 50 to 70 years (Myers 1990); old trees devel op heartrot, which makes them susceptible to windthrow. Fire in rosemary-dominated scrubs occurs very rarely because these shrubs are slow to build up enough fuel to ignite. Rosemary is also killed by fire, and depends on seeding for reestablishment. Other scrub species that recover through establishment of new seedlings include scrub balm species, Ash's calamint, and short-leaved rosemary (Conradina brevifolia; federally listed as endangered). However, many shrubs characteristic of Florida scrub undergo vegetative reproduction rather than seeding following fire, including oaks, saw palmetto, and scrub palmetto (Stout and Marion 1993).

Many rarer scrub plant species seem to require the open patches of bare sand left after a fire to establish themselves. Hawkes and Menges (1996) looked at the role that open spaces in scrub play in the development and maintenance of species assemblages. They found the rosemary phase, which dominates many of the higher elevation sites, had many endemic or endangered herbs growing in light gaps and that the densities of most obligate-seeders or mixed strategy herbs increased as the amount of open spaced increased. The lower elevation sites had a more closed structure, and showed lower herb densities, with more resprouting species evident (Hawkes and Menges 1996). Gaps in lower el evation sites began to close after 10 years since the last fire, whereas gaps in the rosemary phase persisted for decades. This may explain why seeders and herbs prevail in rosemary-dominated scrub communities.

The processes that determine gap dynamics and abundance may influence the distribution and abundance of many scrub species (Menges and Hawkes, in press). The presence of these gaps may even be a more important predictor of species abundance than fire. These open microsites are created when large fuel loads burn in a fire. The long period of intense heat that results from burning slash piles, wind blown snags, or other large, concentrated fuel sources, kills the rhizomes and other parts of plants that would otherwise resprout after a fast-moving fire. This leaves an open area that can then be exploited by species reproducing via seed. Alternatively, these gaps are created by road building and other mechanical disturbances, such as blowouts in coastal scrubs, pits and mounds created by treefalls, or animal burrows and mounds (e.g., gopher tortoise burrows; reviewed in Myers 1990). Wireweed (Polygonella basiramia; federally listed as endangered) grows in bare sand patches within sand pine or Florida rosemary scrub, and management information states that "an adequatesupply of open areas are needed between large shrubs" for habitat (Howie 1994). Similarly, large-leaved jointweed (Polygonella macrophylla; a federal SAR) grows in sandy soil in areas where there are natural openings in the sand pine canopy, or along paths and powerline rightsof-way. Florida perforate cladonia (Cladonia perforata; federally listed as 
endangered) also inhabits sunny, bare sand between scrub vegetation (USFWS 1995).

Many studies have been conducted on the effects of fire on scrub and the post-fire recovery of scrub vegetation, particularly in inland, peninsular scrubs. Scrub is considered highly resilient after fire. Many scrub species, including oaks, palmettos, and ericads resprout rapidly after such an event and return to preburn levels within a few years. One study by Schmalzer and Hinkle (1992) looked at a coastal peninsula oak-saw palmetto on Merritt Island. They sampled a total of 24 transects in 4 study sites before the burn and at $6,12,18,24$, and 36 months after thefire and determined that the changes in the oak-palmettostands were minimal. While the oak dominated transects showed the greatest resistance to change, the saw pal metto-dominated transects showed the fastest rate of recovery. Many other communities show marked changes as a result of fire, but no species were lost due to the fire in this scrub, nor were there any new species present that were not there before the burn. Fires in scrub revitalizes the populations of the plants and shrubs found in this community; it does not initiate sucession in the classical sense. This illustrates how scrub plants are well-adapted to fire.

Whether or not many scrub plants depend on fire as the only mechanism to maintain thestructural features of this communtiy is not dear. A study comparing effects of fire followed by salvage logging, with effects of mechanical treatments (combinations of clearcutting, rollerchopping, broadcast seeding, and brack seeding) in the absence of fire, has shown that many scrub species (though not all) respond similarly to both treatments (Greenberg et al. 1995), but a burn-only treatment was not included in this study. For example, Greenberg et al. (1995) found that Florida rosemary germinated in sites that were both burned and salvage logged, and in sites that weremechanically disturbed but not burned, suggesting that mechanical disturbances, or the consequent conditions, may stimulate seed germination. Similarly, many rare scrub plants proliferate after mechanical disturbances to the soil such as plowed fire breaks and sand roads. Some of the largest populations occur in these areas and where scrub was cleared in the recent past (Myers 1990). However, Greenberg et al. (1995) observed some response differences between treatments, which suggested that effects of fire differ from those of mechanical treatments alone: saw palmetto recovered significantly better in sites that were both burned and salvage logged than it did in mechanically treated sites; similarly, rusty lyonia densities were higher in sites that were both burned and salvage logged compared to only mechanically treated (Greenberg et al. 1995). Increased post-fire vigor has been documented in 14 scrub plants (Berry and Menges 1995). 
Though there are few studies of the effects of fire on scrub soils, el evated levels of phosphorus have been found in these soils following fire. Berry and Menges (1995) believe that in the absence of fire, the growth and reproduction of scrub plants is limited by phosphorous availability. They are using a fertilization experiment to determine which resources limit the vigor of the dominant scrub plants. Schmalzer and Hinkle (1991) found few changes after fire but did note a delayed increase in amonium-nitrogen and nitrate nitrogen.

Little information is available regarding how various scrub plant TES will react to fire. If scrub species resprout following fire, populations should be able to recover quickly. Species that persist as a seed bank between fires should easily recover as well, and fire may stimulate their germination and growth. However, species that must seed into scrub from refugia are likely to be at the greatest risk from fire, because scrub habitat is very limited in area, and many rarescrub plant species are confined to specific types of scrubs (e.g., only rosemary scrubs) or have restricted geographic ranges. Most scrubs recover quickly following a fire.

Florida Rosemary scrub is one phase of Florida scrub that does not recover quickly after fire, but some of the endangered plants that are associated with rosemary scrub, such as wireweed, show greater density and seed production when open areas between rosemary shrubs are abundant (Hawkes and Menges 1995; Menges and Kimmich 1996). Wedge-leaved snakeroot, another endangered herbaceous endemic scrub perennial, also shows the greatest survival when the densities of Florida rosemary are low following a fire. These plants take advantage of the open areas left after a fire and repopulate burned areas through both reseeding and resprouting reproductive strategies (Menges and Kimmich 1996). Their survival decreases as the distance to the nearest Florida rosemary shrub decreases. This may be due to some allelopathic properties of the shrubs or other below-ground competition.

Fire may pose a severethreat to the Florida perforatelichen (USFWS 1995), which is destroyed by fire, and must recolonize a site by spores and fragments $(\mid$ ohnson and Abrahamson 1990). It takes decades for lichens to reestablish following death from fire (J ohnson and Abrahamson 1990). Studies have shown that other nonvascular taxa weremoreabundant in mature forest than in mechanically disturbed or burned sites (Greenberg et al. 1995). Several vascular plants are listed in the Recovery Plan for Nineteen Central Florida Scrub and High Pineland Plants (revised) (USFWS 1995) as not likely to survive fire (e.g., scrub lupine [Lupinus aridorum; federally listed as endangered], paper-like nailwort, short-leaved rosemary, Highland's scrub hypericum [Hypericum cumulicola; federally listed as endangered], and Lewton's polygala [Polygala lewtonii; federally listed as 
endangered]), but none of these species are known to occur on installations. Wireweed may or may not survive fires (USFWS 1995). Long-lived herbs that presumably resprout following fire include: pigeon-wings (Clitoria fragrans; federally listed as threatened), and scrub buckwheat (E riogonum longifol ium var. gnaphalifolium; federally listed as threatened; USFWS 1995), and Eulophia (Pterogl ossaspis ecristata; a former federal candidate species), a forb that benefits from prescribed burning (Russo et al. 1993).

Scrub fauna also depend on areas created by fire and other, localized disturbances in scrub. Gopher tortoises prefer and attain their highest densities in grassy, sparsely canopied sites (Auffenberg and Franz 1982), and even though they typically forage in nearby sandhills that support more grasses and ground cover, gopher tortoises often burrow in the light gaps within scrub. In the absence of fire, young fire-intolerant scrub oaks will become established in the bare patches and may shade out any ground cover used by the tortoises here. Fire frequency is the single most important factor influencing habitat structure and food sources for the gopher tortoise in Florida scrub.

Similarly, open patches are also important as foraging sites for Florida scrub jays. Scrub jays forage as familial groups and require low shrubs and scattered open areas to do this. They use these clearings between scrub thickets for safety purposes while searching for food. One member of the group perches in a conspicuous place and acts as a sentinel as the remaining group members forage. If the sentinel detects a predator, this individual alerts theothers with a distinctive warning call and the entire group flees to denser cover (McGowen and Woolfenden 1989). Without an open understory, this warning system does not work, and the jays are more vul nerable to predators stal king them from conceal ed vantage points. Therefore, jays avoid communities with a closed understory and will abandon open scrub when a heavy pine canopy develops, or when the height of the shrub layer reaches critical levels (Myers 1990). These birds use these open areas to store food as well. Scrub jays are omnivorous, but acorns serve as their principle plant food (USFWS 1990b). They harvest the acorns right off the oak trees in the fall and bury them by the thousands in these bare, sandy patches between the shrubs (DeGange et al. 1989). Thesecached acorns then serveas a food source through out the year.

Because prime jay habitat is maintained by fire, scrub jay populations will begin to decline when their territories show signs of succession. Data collected on the Merritt Island populations at Kennedy Space Center, Cape Canaveral Air Station and the Archbold Biological Station indicate that even large resident populations are declining due to habitat degradation (Mitchell 1997). Fire suppression in remnant areas of scrub reduces the jays' ability to survive and reproduce 
(Woolfenden and Fitzpatrick 1991). Tracts experiencing infrequent fires or fire suppression become overgrown. Tall, dense oak understories and a closed canopy of sand pines result. Preferred scrub jay habitat has scrub with oaks 1 to $3 \mathrm{~m}$ tall covering 50 to 75 percent of the area, and no more than 15 percent canopy cover by trees. Prescribed fire will prohibit scrub from undergoing succession to a closed canopied community and will prevent shrubs from reaching a height that is unsuitable for jays. Wool fenden and Fitzpatrick (1991) estimate that about 50 years post-fire is the longest scrub jays would stay in an area before the habitat became unusable.

One mammalian TES, the Florida mouse, is listed as a species of special concern by the state of Florida and is under review for listing by the U.S. Fish and Wildlife Service (Humphrey 1992). Its decline is associated with habitat loss and fire suppression. This mouse is restricted to the fire-maintained xeric communities of peninsular Florida and has one of the smallest geographic ranges of any mammal. TheF lorida mouse is another burrow-dwelling species that takes advantage of preexisting gopher tortoise burrows (Layne and J ackson 1994). Florida mouse populations are highest in the early successional stages of scrub following a catastrophic fire (Humphrey 1992). Like the scrub jay, their numbers begin to decline as the scrub becomes more shady and dense. The number of years post-fire the habitat remains suitable for the Florida mouse is variable. These mice have persisted in one scrub located in Levy County F lorida for 44 years since the last fire, but population density suffered a sharp decline about 10 years after the fire (Humphrey 1992). Declines in acorn yields from the scrub oaks is probably one factor that accounts for the reduced suitability of Iong unburned, overgrown scrub habitat for both the Florida mouse and Florida scrub jay (Humphrey 1992).

\section{Management Recommendations}

Available information suggests that fire is essential for the maintenance of most Florida scrubs. Natural fires are catastrophic in scrub (meaning they kill off the canopy trees), but without fire, pyrogenic inland scrubs will succeed to a different community and will no longer support scrub-dependent TES populations. Therefore, instituting a fire management plan that mimics natural processes is the best way for managers to restore and maintain Florida scrub. There is no specific fire return interval applicableto all scrubs, and there is no definitive way a natural scrub should al ways appear. Management guidelines should reflect the desire to maintain patches of scrub in different stages, each providing important structural attributes, across the entire landscape. Thus, managers will need to apply fire in a way that promotes all the various stages of development in large fragments of scrub. This practice will allow managers to maintain populations of all the TES 
species having special habitat requirements (reviewed in Myers 1990, Christman 1995). F or example, Christman (1995) suggested that Camp Blanding scrubs are in need of management (prescribed fire) when more than 50 percent of the scrub area that could theoretically support scrub jays has become unable to do so because of vegetative growth since last fire (this figure is subject to adjustment).

Prescribed fires must mimic natural fires in that the burned areas should not be contiguous. Some patches must remain unburned so all species will have refugia, forage, and cover. According to Woolfenden and Fitzpatrick (1991), optimal fire frequency to maintain scrub jay habitat is every 8 to 20 years. They claim that intervals less than 8 years may keep young oaks below acorn-bearing height and could favor the spread of palmettos, which could eventually replace the oaks. However on Merrit I sland, scrub oaks frequently bear acorns only 2 to 3 years postfire (P. Schmalzer 12 May 1998). Therefore, more frequent fire intervals may be appropriate under some circumstances. Christman (1995) suggested that Camp Blanding scrubs should have bare sand covering more than 10 percent of the ground. This recommendation would be achieved with the fire interval used to maintain jay habitat. Florida mice also favor the conditions that support Florida scrub jays and a fire interval that promotes these conditions. Habitat maintained in this way is ideal for other scrub-adapted vertebrates as well. Most scrub endemic shrubs and forbs also prefer these conditions (reviewed in Christman 1995). Therefore we also recommend that scrub be burned at the 8- to 20-year interval suggested by Woolfenden and Fitzpatrick (1991) to manage scrub for TES on military installations, unless the site is one of particularly low productivity (e.g., rosemary scrub), in which case fires may be of an even longer interval.

These recommendations however, are not universal. It is critical that the possible effects on other scrub endemics be considered when using the scrub jay (or any other organism) as an indicator species for scrub management. Those natural resource personnel managing a site for two or more scrub endemic species with incompatible habitat requirements will need to incorporate these differences into the design of their management plans and fireschedule. In this instance, managers must devise a plan that will promote the survival of all TES species living in the area. For example, consider the negative correlation between abundances of Florida scrub jays and sand skinks reported by Mushinsky and McCoy (1995). This phenomenon could posea real problem for managers because, although both species seem to have similar habitat requirements, not enough is known about the relationship between the two to allow managers to make compromises that will be constructive on a bi-lateral basis. For now, the best solution is to look for creative ways in which to manage an area for both species. Since the sand skink and scrub jay are able to coexist on Archblod Biological Station, we should look there for possible alternatives. Sand skinks have been able to persist on Archbold in scrub 
stands greater than 60 years old. These animals are found here in the vicinity of firelanes and other artificial clearings (USFWS 1998). This suggests these artificial dearings may be important to sand skinks. Managers charged with maintaining populations of both species at one installation could leave some old growth stands of scrub unburned. Because these areas are useless to jays anyway, augmenting them with selective artificial clearings and designating them as sand skink habitat is one way to promote both species at one site. This solution shows the importance of incorporating an adaptive management strategy into any management plan.

A shorter fire return interval than the recommended 8- to 20-year period may be necessary if the management goal is to restore scrub in areas that have been left unburned for decades and are severely overgrown. Restoration efforts should include initial frequent fires (every 2 to 4 years) for the first 10 to 15 years (Breininger et al. 1996). This increased fire frequency is needed to reduce the accumulation of underground carbohydrate reserves in enough patches for the openings to return. The ratio of dead to live fuels is important in igniting and sustaining fires in scrub. Breininger et al (1996) believe that 25 percent of the above-ground biomass needs to be dead for effective fires. Thus at least 2 years between burns are necessary when restoring areas with abundant palmetto. At least 3 to 4 years are required between burns for areas of oak scrub with sparse palmettos.

The authors agree that a long term experimental approach will be needed to reestablish openings in densely overgrown scrub, but recommend a variety of ignition techniques and prescriptions to be used to hel $p$ facilitate early restoration fires (Breininger et al. 1996):

1. Use small burn units in a few experimental landscapes.

I gniting burn units less than 200 ha can expedite restoration towards optimal conditions. Small burn units can also be used to investigatefine-scale habitat restoration needs that are essential if reproductive success is to exceed mortality in scrub vegetation.

2. Use ignition strips of mechanically chopped fine fuels.

This will produce intense head fires that can penetrate tall, long unburned thickets of oak.

3. Use narrow stripped, flank fires.

These can also produce the fire intensity required to restore overgrown scrub.

4. Use aerial ignition techniques. 
Delayed aerial incendiary devices (DAIDs) or a heli-torch may benecessary for burning large patches or areas that are not easily accessible. However it is more difficult to ignitescrub with aerial ignition than by ground crews. Aerial ignition will pose a safety hazard when fuel loads are high and should not be used under extreme burning conditions (shifting winds, for example).

These techniques should be used when land managers need to restore severely degraded scrub. Excepts from Christman (1995), Management of Florida Scrub at Camp Blanding, Clay County, Florida, provide specific techniques for maintaining relatively high-quality Florida scrub. Christman (1995) also explained the advantages and disadvantages of using head fires and backing fires to burn scrub and provided information on season of burn and creation and use of firebreaks:

If the management goal...is to maintain and restore natural communities, prescribed fires in scrub should be set in the growing season in adjacent upland communities and allowed to burn with the wind through the scrub and into natural wetland firebreaks. Head fires die out variably as they enter the ecotone with wetlands and this maintains the natural variability of the ecotone. Head fires leave some areas intensely burned and others unburned, creating the habitat mosaic that insures survival of all scrub species. Backing fires, in contrast, tend to burn the groundcover more completely and homogeneously, and to burn hotter at ground level, possibly killing animals and plant seeds near the soil surface. Furthermore, backing fires are difficult to maintain in scrub unless fuels are especially dry. On the other hand, backing fires are easier to control. In cases where maximum control of fire is imperative, backing fires may have to be used.

The use of head fires set in adjacent areas and allowed to burn uncontrolled into scrub is a theoretical technique used to mimic the way natural fires move through these communities. Managers may not be able to apply prescribed fire in this way because scrub is among the most difficult and dangerous plant communities to burn. When igniting scrub, prescribed burners are often fortunate to be able to accomplish their objectives without such fires escaping.

Low-intensity backing fires can be used for safety, but they have met with limited success. Traditionally, scrub will not burn in a backing fire because these fires are difficult to maintain. Backing fires are useless to managers unless they can get the fire into the shrub layer. Fire practitioners have many variables to consider in writing a prescription for a burn, induding wind speed, direction, and variability; 
fuel moisture in both live and dead fuels; air temperature and relative humidity; atmospheric stability and instability; phenology or life stage of the plant and the timing of the burn; fuel size, continuity, load and fuel chemistry as well as a host of possible ignition techniques. Researchers and fire practitioners are beginning to figure out the relationships between these variables, but often the conditions that can sustain a successful backing fire do not exist when the fire is necessary to meet the objectives of the burn.

Managers must have a clear idea of why and when they want to burn and what they want to accomplish with the fire. They should have a specific set of objectives for a fire to meet, and should monitor the site after the burn to see if those objectives have been met (Mary Huffman, Program Director for the Lake Wales Ridge Program, The Nature Conservancy, Lake Wales Ridge, FL, professional discussion, 12 March 1998). Under certain conditions, managers at TNC's Saddle Blanket Lakes Scrub Preserve have been successful in their use of backing fires to maintain Florida scrub (M. Huffman, 12 March 1998), but in general, these fires are not effective in scrub management.

Again from Christman (1995):

Scrubs should be burned during the growing season because that is the period during which most lightning fires occur, and as a result the scrub plants and animals have become adapted to that regime. The best time to burn Florida scrub is in March, April or May...Long unburned scrub cannot be managed with winter fires...such fires, if they can be maintained at all, appear to hasten the degradation of scrub and its conversion to pioneer hammock by eliminating much of the ground layer but little of the larger woody vegetation. Whereas growing season fire in sand pine forest or pioneer hammock will kill the sand pines and above-ground parts of the oaks, thus favoring scrub, fire in the dormant season will burn little but the ground litter.

Abrahamson and Abrahamson (1996) conducted a study on the effects of such a lowintensity, winter burn in a long-unburned scrub on the Archbold Biological Station. Their 7-year examination showed therewas littlechange in thefloristic composition of post-burn stands compared to pre-burn stands, despite a wide variety of recovery strategies to such a burn. The populations of endemic herbaceous plants in this scrub were unable to be restored. Sand pine was likewise unable to regenerate itself as the dominant species in the canopy. 
These results suggest that only fires occurring during the growing season will effectively promotescrub regeneration and halt succession to other cover types. But according to the most recent management practices and data collected on Merrit Island, it is the intensity of the fire, not the season in which it occurs that dictates the success of prescribed burns at restoring and maintaining scrub. Under the proper burning conditions (i.e., appropriate fuel moisture, humidity, temperature, and wind speed), managers at Kennedy Space Center have successfully restored long-unburned scrub by igniting high-intensity fires in November, February, April, and other times of the year (P. Schmalzer, 12 May 1998). Natural resource personnel at Avon Park Air Force Range have also had success with non-growing season fires in maintaining scrub at this installation (J im Orzell, Botanist, Avon Park Air Force Range, professional discussion, 26 J une 1998). Again, adaptive management is the key to successfully maintaining scrub habitat.

Christman (1995) goes on to say:

The timing of subsequent prescribed fires in scrub should be variable, because no single fire-return interval could support the diversity of fire recovery strategies and habitat preferences observed in native scrub species...

Prescribed fires are best ignited along existing roads [except those running through ecotones], and allowed to burn up to and through the scruband intonatural wetland firebreaks...I f artificial firebreaks, either baselines (where the fire is started) or control lines (meant to stop the spread of fire), must be constructed, they should be temporary, created by various combinations of mowing, crushing, burning, or fire suppressant foam. Roller chopping with heavy drums should be avoided because it can adversely affect animal habitats and soil processes, damage plant roots and rhizomes upon which scrub regeneration is dependent, and create habitat for invasive species. Roller chopping with empty roller drums may be acceptable where mowing is impractical.

...Experience at The Nature Conservancy's Tiger Creek Preserve in central Florida has shown that when it is dry enough to ignite a scrub, it may betoo dry to use natural wetlands as a firebreak because the duff and humus in the wetland/scrub ecotone may catch fire and smolder for weeks, causing unacceptable smoke problems on adjacent lands...This may not be a problem [where] scrubs... are relatively isolated on roads and residential areas. Certainly the humus and duff in wetlands, and especially in wetland ecotones, burned under natural conditions prior to management by modern man. Today's accumulation of surface organic matter...is probably greater than at most times in the past... Reduction 
of duff exposes bare mineral soil, which favors establishment of firedependent plant species. Some reduction of accumulated duff in wetland/scrub ecotones should bea goal of natural systems management. On the other hand, if smoke from smoldering duff and humus is deemed unacceptable, managers may wish to pre-burn above ground vegetation in wetland firebreaks when it is possible to do so without igniting the humus, then burn the scrub toward the wetland on a later, drier date when the scrub will burn. By pre-burning the wetland firebreak when the Keech/Byram Drought Index (Keech and Byram 1968) is <350, managers can reduce fuel there without igniting the humus (Melton 1989).

In general, prescribed fires in Florida scrub should be ignited early in the growing season (March-May) while the vegetation is still relatively dry. If igniting the duff within the wetland firebreak must be avoided, the scrub should be burned when the wetlands are flooded and the duff is fireproof but the scrub itself is dry enough to burn. Prescribed fires in scrub that will not depend on availablewetlands for firebreaks can be set anytime between March and J uly.

Managers should apply fire to maintain all of the various stages of scrub within the community. This is a challenging problem, because fire in scrub is high-intensity and often occurs under extreme weather conditions, thus it exhibits uncontrollable and unpredictable behavior (Cox and Roberts 1995). For this reason, wildfires have been the rule, and there is little literature available on prescribed burning in scrub (reviewed in Christman 1995; Doren, Richardson, and Roberts 1987; Kenner 1994). The best control of fire in scrub is proper planning (Christman 1995), as plow-lines are often ineffective in scrub, and attempts to control the fire in scrub by using people, equipment, and tools after the fire has begun often have been futile (Doren, Richardson, and Roberts 1987).

Managers are beginning to use fuel models to predict fire behavior in scrub (Doren, Richardson, and Roberts 1987; Cox and Roberts 1995). Environmental parameters, such as relative humidity, temperature, etc., are input into fuel models to predict the rate of spread and intensity of a fire (Doren, Richardson, and Roberts 1987). In addition, an available computer program (RXWINDOW) can use input from fuel models to determinethe best environmental conditions (e.g., humidity, wind speed) for achieving desired results (e.g., tree mortality, flame length, rate of spread, and intensity) from prescribed burns (Christman 1995).

There is not a specific fuel model for Florida scrub. The National Forest Fire Laboratory (NFFL) fuel model for chaparral/high pocosin/mature scrub has been 
used with success for prescribing fire in the Yamato scrub, one of the last vestiges of this community al ong the Atlantic Coastal Ridgelocated near Boca Raton (Doren, Richardson, and Roberts 1987) and in sand pineforest of the Ocala N ational F orest, Marion County (reviewed in Christman 1995). Methods for burning the Yamato scrub (Doren, Richardson, and Roberts 1987) are presented:

Fire was prescribed to the Yamato Scrub, $\mathrm{FL}$, based on predictions from the National Forest Fire Laboratory (NFFL) fuel model for chaparral/high pocosin/maturescrub. This model was chosen because it presupposed vegetation structure and qualities similar to those for the Yamato scrub. Based on model predictions for maximum spotting distance and probability of ignition, it was decided that some site preparation was necessary to ensurea successful burn. Strips of crushed vegetation were created around and/or across proposed burn sites using a small, empty roller drum chopper weeks before the burn. The number of strips used depended on the size of the site being burned. One pass over the vegetation, with drums set parallel to each other, produced a light slash, without appreciable soil disturbance or fuel compaction. Within the chopped areas, sand pines were dropped on site to reduce spotting potential and create hot spots to prepare a seed bed and open areas for vegetation and wildlife. About 2 weeks without rain were required to dry out the crushed fuels sufficiently and reduce fuel moisture to prescribed levels. When weather conditions were favorable, managers torched the downwind edge of the crushed area, then moved up each side until the first alternating chopped strip was reached, then fired across the strip, creating a head fire through the unchopped scrub area. This resulted in alternately blacklining (burning out fuels around the fire) and head firing the entire area, which aided in reducing overall intensity and direction of each headfire, and created manageable smoke and fire conditions. Managers were able to burn most of one site and all of a second site, because weather conditions were favorable. Development of unfavorable weather conditions as the day progressed prevented complete burning of the first site, and all further ignition attempts were futile. The effects of roller chopping on the soil were minimal...Thefirebehavior predictions wereremarkably accuratefor the prescribed burns.

Christman (1995) also described the use of prescribed fire to burn several overgrown scrubs on Merritt Island: 
On Merritt I sland, managers used a Brown treecutter, a D-6 Caterpillar with a V-blade, or a roller chopper to prepare strips and blocks within several long-unburned oak scrubs prior to burning (Schmalzer et al. 1994). After drying for a week or two the crushed strips were easily ignited with a drip torch. By the time the heading fire reached the uncut scrub it had built up sufficient intensity to carry into the standing vegetation. Managers at Merritt I sland reported that the Brown tree cutter provided the best results, producing the best fuel bed with almost no soil disturbance.

Christman (1995) provided other examples of methods used to prescribe fires in Florida scrub. At Saddle Blanket Lakes Scrub Preserve, temporary firebreaks were created by mowing, and then burning the mowed strips. In sand pine scrub at Archbold biological station in Highlands County, and in sand pine forest in the Ocala National Forest in Marion County, linear backfiring was used to develop burned strips that would serve as baselines and control lines. Scrub at Oscar Scherer State Recreation Area in Sarasota County was mowed with a Brown tree cutter prior to burning (reviewed in Christman 1995).

An alternative method for restoring Florida scrub was used with some success at Blue Spring State Park (Kenner 1994). The use of a hot, fast-moving crown fire was a problem in this case, because managers didn't know how to keep these fires from damaging nearby housing and park facilities. Therefore, a combination of clearcutting sand pine to reduce fuel load was followed by a prescribed burn.

The 10-ha tract of scrub was clear-cut in the fall of 1989 and was burned in March 1990. Comparisons of pre-treatment and post-treatment data indicated a significant increase in plant diversity, especially grasses and legumes. A rise in animal diversity and abundance was al so observed, including appearances of scrub jays on the tract in 1992, with two becoming permanent residents by summer of 1993. A Florida scrub lizard and an Eastern coach-whip, new species for the park, were also seen in 1992. Although no tortoise burrows were found in the park the day after the area was burned (they were rare in the park), the return of gopher tortoises has since been observed, and at least 18 burrows have been located. Some substrate disturbance occurred around the staging and loading area, but no exotics were observed to date.

Kenner (1994) provided management recommendations based on results from this study: 
! Cut sand pine in February, March, or April. This allows the slash approximately three months to dry, so that it may be burned before excessive sprouting occurs.

! Cut thetrees with a rotary feller-buncher. This will reduce the dense understory shrub layer to a fuel texture and arrangement that carries fire well under low to moderate wind conditions. List the use of a rotary feller-buncher as a requirement in the timber sale contract.

! Limb trees where they fall, to evenly distribute slash over the site. Do not use limb-removal devices that lead to the accumulation of large amounts of slash in a small area.

! Locate the loading area on previously disturbed sites whenever possible, to minimize the extent of ground disturbance caused by skidders and trucks.

Another study by Boyle, Schmalzer, and Adrian (1998) compared the use of fireand a combination of mechanical cutting and fire on the restoration of long-unburned scrub on Kennedy SpaceCenter/Merrit Island National Wildlife Refuge. They used 15-m transects to sample the restoration sites pre-treatment and at 6-month intervals post-burn. Both the scrub oaks and saw palmettos resproughted after all treatments, but the palmetto recovery was less in all treatments involving mechanical cutting than with fire alone. Recovery of oaks was similar in all treatments. Persistent openings were produced only when cut brush was piled for burning and the prolonged heat killed the rhizomes and roots of the shrubs (Boyle, Schmalzer, and Adrian, 1998).

Examples have shown that prescribed fire can be used to restore scrub habitats if burns are carefully planned and applied. If fire is applied in conjunction with dearcutting or other forms of mechanical disturbance, methods causing the least amount of mechanical disturbance to the soil are preferred, as soil disturbances may lead to invasion by weedy species (Eric Menges, Senior Research Biologist, Archbold Biological Station, professional discussion, 5 February 1996).

In cases where use of fire in scrub is not feasible, managers should consider the use of mechanical disturbance as a tool to maintain scrub. The response of scrubs that have been chopped or mowed but not rootraked appears to be similar to the response from burning, but more study is needed. Significant differences between fireand mechanical disturbance without fire in Florida scrubs have not been found, 
but studies have had poor controls. Florida Park Service biologists at J onathan Dickinson State Park are addressing this question (D. Roberts, Biologist, Florida Park Service, professional discussion, 11 March 1998). The U.S. Fish and Wildlife Service is funding their research for management of listed species in Florida scrub. The researchers have set up experimental plots in mature scrub to compare different treatments of mechanical disturbance, fire, and the two treatments combined. In one treatment, biologists at the park used a Brown tree cutter to remove the trees in a plot they subsequently burned with prescribed fire. They allowed that fire to burn into an adjacent plot of undisturbed sand pine to compare responses of scrub vegetation. In another plot they shredded 100 percent of the understory biomass with an Alamo shredder, leaving the sand pine overstory and a mulch that will contribute to nutrient cycling. They will compare the results of this treatment with those of a fire. The data have not been analyzed yet to determine the responses, but managers should keep abreast of new information from this study and others.

The U.S. Forest Service has been able to maintain Florida scrub jay habitat by mechanical harvesting and regenerating sand pine in the Ocala National Forest (USFWS 1990b) without the use of fire. Managers used clearcutting techniques to remove the sand pine in blocks of 120 acres. New cuts are made adjacent to older cuts that have been mechanically reseeded to make large areas of suitable jay habitat. J ays are able to use these areas for about 10 years before the pines mature to the point wherethe habitat is no longer suitable. As much as 20 percent of forest is available to jays at any one time. The Ocala National Forest boasts more than 700 breeding pairs - the largest population in the state (L. Lowery, 25 February 1998). The USFS is able to maintain populations of other vertebrate TES at this location as well, including the eastern indigo snake, Florida mouse, Florida scrub lizard, short tailed snake, gopher frog, Florida pine snake, and sand skink. Problems with soil compaction and disturbance are minimal (L. Lowery, 25 February 1998). In areas where prescribed burning is not an option, this method of managing scrub could be used as an economically profitable alternative. When using these mechanical disturbance techniques to maintain scrub, care must be taken to minimize damage to plant root systems and rare ground lichens. (See Groundcover Disturbances.)

This type of disturbance may be helpful in managing rare plant species as well. Menges and Kimmich (1996) recommend that rosemary scrub patches with wedgeleaved snakeroot be burned every 10 to 25 years or by such time that the gaps between the shrubs becomesmall enough so that most snakeroot plants are within $60 \mathrm{~cm}$ of the shrubs. However, they also state that because this plant has been found to grow vigorously along firelanes and in other areas where the soil has been 
subjected to disturbance, mechanical disturbance could well be used to manage this plant.

There is one final point on this subject: scrub has an evolutionary history involving adaptation to fire. At this time there is no scientific consensus that scrub can be maintained in the long term by mechanical disturbance alone.

\section{Alteration of Hydrology}

\section{Impacts}

Altered hydrology is not likely to be an issue for F lorida scrub plants. Ground-level disturbances are not likely to interact significantly with local hydrology and these plants are adapted to live on the well-drained, droughty soils supporting scrub. Many scrub species have deep roots to access soil moisture at considerable depths, in addition to a shallow root system, so moisture stress is not a problem. Surprisingly, flatwoods plants may be more likely to experience water stress than scrub plants, because flatwoods plants are shall ow rooted (probably due to the high water table). Nutrient deficiency likely plays a greater role in ecosystem structure in scrub than water deficiency (reviewed in Myers 1990). Altered hydrology may indirectly affect firefrequency in scrub communities if the natural barriers between the scrub and the adjacent fire-maintained communities become dry enough to carry fire. If surrounding wetland areas aredrained or their hydrology is otherwise changed to the point where these areas become more xeric, they will no longer function as a barrier to fire and adjacent scrub will burn with an increasing frequency.

Altered hydrology in surrounding wetl and areas can negatively affect F Iorida scrub in another way. Many fresh water marshes in Florida burn readily and act as an ignition source for scrub in years when it has a fuel load high enough to burn. Fire frequency can be reduced in these wetlands when the hydrology is altered to the point where red maple (Acer rubrum), willow (Salix caroliniana), wax myrtle (Myrica cerifera), and groundsel (Baccharis spp.) become established. These and other trees and shrubs are much less prone to fire than those they may replace, and the overall fire frequency in these areas will be lower here, and in adjacent scrub (P. Schmalzer, 12 May 1998). 


\section{Management Recommendations}

Avoid hydrological alterations that could dry out the surrounding wetland areas that serve as barriers protecting scrub from fires ignited in more pyrogenic communities. Engineers should refrain from hydrological alterations that promote the germination of plants that would decrease the fire frequency in these wetland areas.

\section{Groundcover Disturbances}

\section{Impacts}

Many scrub species show a similar response to burning and to mechanical disturbances, suggesting that the mechanical disturbances resulting from clearcutting may mimic the natural disturbance process (Greenberg et al. 1995). Greenberg et al. (1995) note that scrub should be adapted to mechanical disturbance, because coastal scrub is disturbed by sand erosion, deposition, and movement by wind and water, and inland scrub species would have been exposed to similar selective pressures, as they occurred at one time on coastal dunes and barrier islands during higher sea levels. Although many scrub species responded similarly to different treatments, some response differences between treatments were noted by Greenberg et al. (1995). Plant community composition and structural characteristics were measured in mature sand pine scrub and in sand pine scrub 5 to 7 years after different disturbance treatments: (1) high intensity burn, salvage logged, and naturally regenerated; (2) clear-cut, roller-chopped, and broadcast seeded; and (3) clear-cut and bracke-seeded. An increase in ruderals (bluestems, Andropogon spp.) and dog-fennel (Eupatorium compositifolium) occurred in all of the disturbance treatments, though this trend is not commonly reported following fire alone in scrub, suggesting that effects of mechanical disturbance (e.g., post-fire salvage logging) differ from effects of fire. Saw palmetto declined significantly following roller chopping, and increased following salvage logging combined with wildfire. Saw palmetto is important in carrying wildfire, even where sparse, and declines in populations could interfere with fire management (Greenberg et al. 1995). Results of this study should be viewed with caution, because it was not conducted at the time scale or spatial scale necessary to determine whether mechanical disturbances in scrub are sustainable. Furthermore, pretreatment data were absent from the study, and there was no control (burn-only treatment; Greenberg et al. 1995). 
Another study (Breininger and Schmalzer 1990) documented long-term effects in an oak scrub site that was mechanically cleared more than 20 years earlier. In an adjacent non-disturbed oak/palmetto scrub site, the dominant species (in the over 0.5-m layer) were saw palmetto, myrtle oak, and sand live oak. The disturbed oak scrub, in contrast, was dominated by sand live oak with limited saw palmetto. Additional habitat differences noted in the disturbed oak scrub site included (1) more bare ground, (2) a taller shrub layer, and (3) more herbaceous species. It has been noted that weedy and non-native species (dogfennel, cogon grass) are over represented in scrub on the Ocala National Forest when compared to natural scrubs. This abundance may have resulted from site-preparation activities; scrubs are naturally resistant to exotic species invasion, except when soils are disturbed (E. Menges, 5 F ebruary 1996).

Greenberg et al.'s (1995) study did not discuss effects of silvicultural treatments on rare species. Available information suggests that rare species usually do not recolonize a site by seed once the species is killed by root exposure, and if they do, recolonization is very slow. If adults occur in a site before disturbance and are only top-killed, they normally survive (D. Gordon, 5 F ebruary 1996).

\section{Management Recommendations}

In scrubs that have become degraded by fire-suppression, managers should devise ways to prescribe fires that will not cause intensive ground disturbance, as structural changes have been noted foll owing intensive silviculture (Greenberg et al. 1995). Examples have been provided (see Fire and Fire Suppression).

If managers must use mechanical disturbances rather than prescribed fire to restore and maintain scrub, care must be taken to cause as little soil disturbance as possible. Bulldozers and other heavy equipment can be too intrusive in areas of scrub that support communities of rare plants and other terrestrial vertebrates. For example, even though adult gopher tortoises can dig burrows that can be 5 to 10 feet deep and 20 feet or more long (USF WS 1990), these burrows cannot protect the tortoises from the weight of a heavy dozer or tank. Lohoefener and Lohmeier (1984) believe that nests and hatchlings are often destroyed by heavy equipment and intensive site preparation activities within tortoise habitat. Sand skinks and blue-tailed mole skinks spend much of their time just beneath the surface of the sand. These TES can be crushed by vehicles weighing far less than a skidder or dozer.

Management activities are designed to improve TES habitat. I deally, these areas should be cleared and removed by hand, but this recommendation is not realistic 
in all cases. Managers do not have the time or money to perform large-scale scrub management by hand-clearing trees or vegetation. In the process of performing these activities, losses of individual plants and animals will inevitably be incurred. The costs of using heavy equipment in sensitive areas must be weighed against potential gains to TES populations. Long term gains may be worth the price paid by a few individuals. On the other hand, large scale use of heavy equipment may reduce populations to the point where they cannot recover and the habitat created for them will remain unused. Again, managers should seek a compromise through creative and adaptive solutions tothis problem. For example, vol unteer labor could be used to hand-clear the most sensitive areas. Hack and squirt applications of herbicide can be used to kill large numbers of trees in a relatively small amount of time. The trees will die and eventually succumb to windfall, creating an opening for other plants to exploit. Large trees may be girdled and left to die.

Natural scrubs should also be off-limits to off-road vehicles (including four-wheel drive trucks, motorcycles, and all-terrain vehicles [ATVs], unless they are needed during a prescribed burn) and heavy trampling. Many rare scrub species inhabit bare, open areas of sand within the scrub. Without protection, disturbance caused by vehicles and pedestrians is morelikely to beconcentrated in theseareas because they are more accessiblethan the dense oak, rosemary, or palmetto thickets within the scrub. Finally, there is little information available regarding the effects of disturbance on slow-growing, ground-dwelling lichens in scrub. However, they are likely to be sensitive to disturbance by off-road vehicles and heavy trampling and may require 50 years or more to recover after a single disturbance event (FNAI and FDNR 1990).

\section{Erosion}

Topography is the main factor influencing erosion in Florida scrub. The terrain on Camp Blanding, for example, is fairly level and scrub sites here are protected from wind erosion by surrounding woodlands (L. Morris, Camp Blanding, FL, professional discussion, J une 1998 ) Because the sandy soil on which scrub exists drains so rapidly, the erosional forces of rain do not seem to be an issue here. But many scrub communities inhabit fossilized dune systems that were historically formed by the erosional forces of the Florida landscape. The bare patches of loose sand that define Florida scrub today may be subject to wind and rain erosion, particularly when these forces follow ground cover disturbances (FNAI and FDNR 1990). Heavy tracked vehicles and motorcycles could cause problems by promoting erosion, but in the absence of regular vehicle use, erosion can be kept to a 
minimum. Camp Blanding has restricted vehicle traffic in scrublands (L. Morris, J une 1998).

\section{Exotic Species}

Florida scrub may be less invasible than other vegetation types, because of its demanding physical environment and allel opathic properties associated with scrub dominants (USFWS 1995). However, activities that disturb soil can increase susceptibility of F lorida scrub to invasion by species not natural to the community. Coastal scrubs on Cape Canaveral Air Station and el sewhere on the Atlantic Coast barrier islands appear to be more vulnerable than inland scrub to invasion by exotics including Brazilian pepper (Schinus terebinthifolius) and castor bean (Ricinus communis) (P. Schmalzer, 12 May 1998).

\section{Impacts}

Scrub habitat will be more susceptible to invasion by exotic plants whenever nonnative fill dirt is brought into the community. Roadways built through Florida scrub facilitatetheinvasion by non-indigenous species (Greenberg, Crownover, and Gordon 1997) because conditions governing competition and survival become markedly altered. Thesandy soil on which scrub vegetation grows will not compact well and is therefore inadequate for road building. Engineers often bring in lime rock, clay, and other soils foreign to scrub communities to build a road bed in these areas. Soil pH and levels of several nutrients in roadsides often differ significantly from native soils (Greenberg, Crownover, and Gordon 1997). Theseconditions allow thetransport of source propagules to previously unattainable sites and promotethe infiltration of invasive species into scrub habitat. Nutrient enrichment of the lowfertility soils in scrub not only promotes the invasion of non-indigenous species, but often corresponds with a decreasein nativespecies richness (Greenberg, Crownover, and Gordon 1997).

The presence of clay and limestone in scrub can result in potentially higher soil moisture levels. I ncreased run off from compacted road surfaces as well as increased water retention capacity due to a high clay content can contribute to the higher incident of weedy species. These species would be otherwise unable to establish themselves in the xeric soils surrounding the road. I mproved roads also receive greater vehicle use than unimproved sand roads and the potential for propagules to be transported into these sites from distant seed sources is greatly increased. Some of the non-indigenous species of grasses Greenberg, Crownover, and Gordon (1997) noted as appearing along roadsides in scrub include Champagne 
(Rhynchelytrum repens [Willd.] C.E. Hubb.), smutt grass (Sporobol us indicus (L.) R. Br.), and centipede grass (E remochloa ophiuroides [Munro] Hack.), a native of China. They also noted a number of species of herbs indigenous to Florida but uncharacteristic of Florida scrub growing in the study areas. Other exotic plant species either documented as invading or having the potential to invade Florida scrub include Bahia grass (Paspalum notatum), Brazilian pepper (Shinus terebinthifol ius), and cogon grass (USFWS 1995). Table 4 lists some activities that may lead to invasion of exotic species.

\begin{tabular}{|c|c|}
\hline ACTIVITY & EFFECT(S) \\
\hline Hog rooting & $\begin{array}{l}\text { Destroys vegetation and churns up soil, freeing resources for the establishment of } \\
\text { exotics. Feral hogs may also be responsible for transporting non-native propagules } \\
\text { into the community. }\end{array}$ \\
\hline $\begin{array}{l}\text { Adding fill dirt } \\
\text { Road construction }\end{array}$ & $\begin{array}{l}\text { May add nutrient-rich soil into a nutrient-poor community. Propagules of invasive } \\
\text { plants can be transported in the fill or may become established along new road beds. }\end{array}$ \\
\hline Fire suppression & $\begin{array}{l}\text { Changes physical characteristics of community so that native species cannot } \\
\text { establish, thereby freeing resources for non-natives. }\end{array}$ \\
\hline $\begin{array}{l}\text { Establishing clearings for } \\
\text { wildlife food plots }\end{array}$ & $\begin{array}{l}\text { Provides open areas that are easily invaded by exotics or species from adjacent } \\
\text { communities (Leblond et al. 1994). Can also foster establishment of exotics, if exotic } \\
\text { species are planted as wildlife food sources. }\end{array}$ \\
\hline Fire plowlines & Suppress fire and create open spaces, freeing resources for non-natives. \\
\hline Revegetation & $\begin{array}{l}\text { Allows for establishment of non-natives, when they are intentionally planted in } \\
\text { revegetation activities. }\end{array}$ \\
\hline Use of off-road vehicles & $\begin{array}{l}\text { Can destroy native vegetation, thus freeing resources for non-natives. Exotic } \\
\text { propagules can be brought into the community on tires of vehicles. }\end{array}$ \\
\hline Fragmentation & $\begin{array}{l}\text { Creates more edge habitat in natural communities, and edges tend to be more easily } \\
\text { invaded by pests than interior habitats. Also creates more land adjacent to natural } \\
\text { communities that supports populations of pest species that invade or prey upon } \\
\text { species within the habitat. }\end{array}$ \\
\hline
\end{tabular}

Cogon grass. Cogon grass has been designated the worst perennial grass weed of southern and eastern Asia and one of the 10 worst weeds worldwide. It has been documented in Louisiana, Mississippi, Alabama, South Carolina, and Florida (reviewed in Coileand Shilling 1993). It becomes established in both pinelands and Florida scrub (USFWS 1995). This species can survive in dry, barren areas where 
other plants have difficulties, because it has a root system efficient at extracting water and minerals (Coile and Shilling 1993). The spread of cogon grass cannot be controlled using fire (Duever 1989).

Cogon grass is spread by wind-dispersed seed and by rhizomes, which can be transported on equipment (e.g., bulldozers; FNAI 1994b, USFWS 1995). Rhizomatous spread and allel opathy aid cogon grass in the production of monotypic stands (Coile and Shilling 1993).

In F lorida, cogon grass can be observed growing al ong roadsides, usually in full sun, forming dense stands of yellow-green grass. A quick identification feature is an offcenter midrib, which is whitish. This feature is more apparent toward the tips of the leaves. Other features are translucent, dry, rough leaf margins (similar to cutgrass [Lersia sp.]), and the presence of many scale-like non-green leaves on the rhizomes (similar to] ohnsongrass [Sorghum halepense]). Plants are usually about $1 \mathrm{~m}$ tall, but very rarely grow to $3 \mathrm{~m}$ tall, and are similar in appearance to J ohnsongrass.

\section{Management Recommendations}

In general, the presence of exotics and pests in natural areas should be viewed as indicators of unnatural disturbances affecting the community. Thus, control should be primarily through preventing the conditions that allow for their establishment. Activities listed in Table 3 should beavoided (whenever possible), as theseactivities increase community susceptibility to invasion by exotics. However, communities may currently have problems with exotics/pests, and management recommendations for their control are outlined below.

Managers should obtain a copy of Langeland (1990), "Exotic Woody Plant Control" and Langel and and Stocker (1997), "Control of Non-NativePlants in Natural Areas of Florida," for information regarding control of exotic plants. These publications can beobtained by contacting thePublications Distribution Center, PO Box 110011, University of Florida, Gainesville, FL, 32611.

In general, manual removal of exotics should cause the least disturbance to the environment, if done carefully. However, manual removal can be labor intensive and may not work for large trees. When using manual methods, every effort must be made to remove the entire root system, because some species can resprout from only a 1/4-inch section of root (Langel and 1990). Only manual removal should occur in high-quality sites, unless it is determined that more intensive methods (e.g., 
chemical removal) are absolutely necessary to eliminate exotic or pest plants. Manual removal is also the preferred method in intermediate quality sites.

Mechanical removal (e.g., using bulldozers, specialized logging equipment) should be avoided in natural areas because it causes severe disturbance to soils and nontarget vegetation. Mechanical removal should be used only when an area is being cleared for new land-use. Mechanical removal also requires follow-up treatment, as exotics will be quick to reinvade (Langeland 1990). Mechanical removal should only be allowed in moderately low quality and lowest quality sites. In these cases, the least disturbance methods should be used, and wetland protection and erosion measures should be taken.

Herbicides have been used successfully to remove woody exotics. Avoid herbicides within or immediately adjacent to TES or any permanent or seasonal wetlands. Herbicides can affect water quality and present a direct threat to rare species (Russo et al. 1993, USFWS 1983). Because of the risk of drift effects on TES and other non-target species, herbicides should not be used to control exotics in highquality sites, and should not be used in intermediate-quality sites unless control is needed over large areas and manual removal is not feasible. However, because some exotics (e.g., Cogon grass) pose a serious threat to natural communities and are very difficult to remove manually, herbicides can be used.

If herbicides must beapplied, the method and timing should beselected to minimize effects on non-target vegetation and the environment. The herbicide applicator must be well informed of the chemical properties of the herbicide, and under what circumstances it should be applied. Environmental precautions are stated on the herbicide label. In general, these guidelines should be followed:

! Only the minimum recommended amount should be used (Department of the Air F orce 1993).

! Herbicides should never be applied aerially in natural areas. Use only direct application techniques, such as spot treatments, to ensure the herbicide contacts only target plants.

The applicator also should be aware of potential weather conditions and should schedule applications accordingly (Langeland 1990):

! Heavy rainfall following application may result in damage to non-target vegetation. Drought conditions preceding application can affect herbicide 
efficacy, because drought-stressed plants are less likely to absorb herbicides.

! Excessive wind may result in poor coverage to the target vegetation and cause drift that results in damage to non-target vegetation. Excessive wind can indirectly affect the ability of the plant leaves to absorb herbicides.

! At less than optimum temperatures, plant growth slows down, which may decrease herbicide absorption or activity. 
Management Regarding Cogon grass. Specific recommendations for management of Cogon grass were provided by Coile and Shilling (1993):

Managers are advised to refer to the control measures in the IFAS publication "Cogon grass (Imparata cylindrica (L.) Beauv. Biology, Ecology and Control in Florida" by Colvin et al. 1994. Glyphosate (Accord or Roundup) $^{* *}$ or imazapyr (Arsenal) are probably the best herbicides to control Cogon grass where they can be applied. Several treatments are necessary for effective control. The dead leaves of Cogon grass remain upright and do not decay easily, and these prevent herbicides from being effectively absorbed. For effective control, herbicide should be applied to living, green leaves, which will allow transport to rhizomes. Late fall is the best time to apply herbicides because plants are sending carbohydrates to roots and rhizomes for storage, and at this time the herbicide will also be translocated to rhizomes. Killing of rhizomes is necessary to control Cogon grass. It is essential to apply a herbicide after cultivation or burning.

\section{Fertilization}

\section{Impacts}

Because Florida scrub appears to bestructured by nutrient stress (Myers 1990), the use of chemical fertilizers in and near Florida scrub may have drastic effects on the community. Native scrub vegetation does not need supplemental fertilizers to establish themselves and compete in scrub soils. Weedy species can out compete scrub vegetation following nutrient enrichment. These include the exotic species referred to in the previous section and species native to more fertile soils in F lorida.

\section{Management Recommendations}

Use of fertilizers is not recommended and should be avoided in high-quality and intermediate-quality sites that support native scrub vegetation. In sites that are not restorable, fertilizers should be used with care, to assure that they will not enter wetlands.

\footnotetext{
${ }^{* *}$ Using glyphosate to control Cogon grass will also eliminate wiregrass and associated species (in Duever 1989). Since glyphosate and imazapyr are both broad spectrum herbicides, they will kill all or most plants that they come into contact with. Thus, care must be taken to avoid damage to nontarget, desirable vegetation (L angeland 1990).
} 


\section{Summary}

Despite their barren appearance, natural scrub communities in Florida are biologically diverse ecosystems. They provide habitat for at least 13 plant and at least 10 animal TES. Many of these are protected under the Endangered Species Act. Under some circumstances, it is desirable to maintain high-quality natural communities to provide habitat for multiple native species over large areas. In particular, this strategy works well as part of the Integrated Natural Resources Management Planning (INRMP) process, within an ecosystem management framework. The recommendations made in this report are intended to be applied in areas where TES conservation is the primary focus of land management, but other activities are desired to the maximum extent possible. Other management choices are appropriate in areas where TES management is less imperative.

It is beneficial to manage TES habitat using an ecosystem-based approach, (i.e., land use objectives combined with knowledge of ecosystem processes), which can help identify the appropriate management techniques for each landscape and each site. Common goals for ecosystem management of TES habitat include the maintenance of natural community composition, structure, and function. Florida scrub is a rare community, defined as a closed to open canopy forest of sand pines, with dense clumps or vast thickets of scrub oak and other shrubs dominating the understory. Ground cover tends to be sparse in this community and open areas of sand are common between the thickets of understory shrubs. These shrubs typically include oaks, palmettos, and rosemary. Florida scrub occurs on the dry, sandy soils that make up ancient coastal dune systems. These soils are excessively well drained and devoid of silt, day, and organic matter, making them poor in nutrients. These environmental conditions make them somewhat resistant to invasion by exotic species. Physiognomy varies markedly with fire history and moisture availability. The ecological quality of sites may be assessed using a combination of these compositional and structural attributes and the quality, in turn, can guide decisions regarding protection and management of the site.

Florida scrub exists within a matrix of other pyrogenic communities. Fire has shaped these communities for thousands of years and they will cease to exist without its continued influence. Knowledge of the processes of succession, hydrology, and fire are imperative to understand how this community developed 
and how land use practices and management effect community quality. Research suggests that the best way to promote high-quality TES habitat in Florida scrub is through the use of prescribed fires that mimic the natural fires of the past. Natural or accidental fires may be allowed to burn in areas where the dangers associated with these types of fires is minimal, but managers will usually need to conduct prescribed burns under controlled conditions.

We recommend a fire-return interval (as outlined in the Fire and Fire Suppression section of Chapter 5) of every 8 to 20 years in Florida scrub, but this interval may be adjusted, depending on the needs of the site in question. Growing season burns are usually necessary in order to ignite a fire in scrub and to maintain the burn. The fire routine should be flexible and coordinated with the needs of military trainers.

Managers must take into account the hazards associated with the high-intensity fire characteristic of burning scrub. Smoke production and the inability to control such a burn must beconsidered when writing a prescription for fire. In areas where the risk of catastrophic fires is too great, al ternative management practices may be used. Low-intensity, backing fires occurring during the growing season have been used for safety purposes, but these have met with limited success. Under certain burning conditions, managers at one of The Nature Conservancy's scrub sites have successfully used backing fires to maintain scrub. In general, however, this community does not burn well using this technique. These fires are hard to maintain in the absence of a heavy fuel load. Studies of this alternative are ongoing. Low intensity, winter burns have also been considered as a safe alternative burning strategy, but a 7-year study conducted by Abrahamson and Abrahamson (1996) showed there was little change in the floristic composition of post-burn stands compared to pre-burn stands, despite the wide variety of plant recovery strategies to such a burn.

Mechanical disturbances are another alternative to fire for maintenance of scrub. Numerous studies show a variety of responses of native vegetation to such disturbances. Breininger and Schmalzer (1990) studied habitat changes in vegetation in one scrub site after it was disturbed by some mechanical clearing that eliminated the saw palmetto. This event occurred on the site 20 years earlier. They noted more bare ground in the treatment area, a taller shrub layer, and more herbaceous species. Weedy and non-weedy plants, however, became overrepresented in disturbed sites when compared to undisturbed sites.

While groundcover vegetation is often top-killed by fire, scrub plants will usually survive by resprouting or reseeding after such an event. However, these plants can 
be killed outright from the direct, physical damage usually associated with mechanized vehicles used in site preparation and maintenance activities. Clear cutting, roller chopping, and salvage logging can disturb the soil to the point that the roots of sensitive plants are exposed, rendering them unable to regenerate. Care must be taken to minimize groundcover disturbances in these areas. When alternatives to fire are necessary, TES habitat should be cleared by hand. Large trees may be girdled and left to succumb to windfall, just as if they had died in a fire. Disturbances of this nature are also common in military training operations. Intensive training, including occupational exercises and assembly activities, generally destroy groundcover much more quickly than it can recover. When these activities must occur in scrub, the repeated use of fewer "designated sites," rather than rotation among many sites will reduce the total area on which groundcover has been disturbed.

Priorities for restoration of Florida scrub may be linked to the support of military training objectives, or to increase the availableTES habitat. Managers have been given information to help them develop an ecosystem-level management plan for their installation's scrub habitat. Several techniques can be employed to enhance the quality of this ecosystem. Prescribed fire, mechanical thinning, and reduction of groundcover disturbances are the major components of restoration efforts. We recommend that studies be conducted on the feasibility of expanding the size and connectivity of existing larger tracts of high-quality scrub habitat with corridors, so species likethegopher tortoiseand eastern indigo snakecan migrate between these larger parcels of land. Managers should attempt to restore those degraded areas that are adjacent to, but currently separate from, high-quality natural communities, in order to minimize effects of fragmentation. Such restoration would also allow natural processes such as fire to continue on a landscape scale.

The spacial arrangement of TES habitat on the entire installation may be an important factor to the survival and reproduction of the listed species. Responses to habitat fragmentation have been documented for gopher tortoises, eastern indigo snakes, and Florida scrub jays. The arrangement of high-quality habitat will also influence the ability of managers to maintain natural processes, such as catastrophic fire events. The creation of a system of land use priorities is one of the best management tactics available to DoD natural resource personnel. Managers should take into account the needs of military training and testing, and the requirements of specific TES populations when making management decisions. In this way, compromises can be made between the two seemingly opposite ends of the spectrum. After consultation with the USFWS concerning TES habitat, multiple land uses may then be permitted within the system of priorities. 


\section{Appendix A: Community Quality Evaluation and Management}

\section{Baseline Data}

To practice sound ecosystem management, with several goals in mind (the military mission, protecting TES, production of forest commodities), installations should gather the following baseline information from which they can make management decisions.

! Locations and sizes of TES populations or significant features within communities.

This will allow managers to avoid direct impacts to TES or significant features, by planning potentially destructive activities away from TES populations, and educating personnel to avoid impacting TES when possible. This information also can be used to monitor effects of management practices on elements of concern.

! Mission land and resource needs to support the training and/or testing mission(s).

! Kinds of plant communities, and the juxtaposition of different communities within the landscape. Managers also should be aware of the relationship between plants and animals in each community and the habitats on which they depend.

Knowledge of kinds of communities is important for community-based management, because management can be applied at the community level. Knowledge about communities, species, and their relationship to watersheds can help managers plan activities so that they cause the least disturbance to el ements of concern. For example, managers would want to avoid creating a barrier between terrestrial habitat for a rare animal species and the watershed it depends upon for breeding.

! Quality and significance of plant communities on the installation.

This information should be used to determine which communities have the highest priority for protection, from a biodiversity/natural heritage standpoint. A community generally is deemed high quality if it 
resembles pre-settlement conditions (see Community Quality and Management, Community Quality). Regardless of quality, the community may be highly significant based on rarity or uniqueness of the type.

! Natural processes that regulate the communities and how they have been altered by anthropocentric activities.

It is not enough for managers to identify all the taxa in a community. The processes that allow ecological succession to regress, stabilize, or accelerate must also be identified in order to manage for appropriate stage in thecommunity's succession. Knowledge of the process allows for the devel opment of ecological models. These models are enjoying a high degree of popularity in the fields of risk assessment and environmental impact analysis. Important processes include fire frequency, human land use patterns, wetland loss or gain, soil erosion, deforestation/ reforestation, community recovery rates (from environmental disturbances), nutrient cycling, soil productivity, community succession and species replacement, exotic species introduction and spread, population turnover, fecundity, and mortality rates.

! Interagency cooperation and data compiling/exchange.

This type of cooperation involves activities such as sharing information and leveraging resources to achieve a common goal. These practices are arguably the most important elements in determining success with respect to an ecosystem management approach to problem solving. Cooperation with non-DoD agencies like TNC and state natural heritage organizations is needed because few, if any installations contain closed ecosystems that support sustainableTES populations. All areinfluenced to one degree or another by species and processes (hydrology, natural and human-induced impacts, etc.) occurring on adjacent lands. Moreover, state agencies and other natural resource-oriented groups often have access to a wealth of unpublished information, in-house expertise, and extensive libraries that can potentially provide much of the baseline data. Not only can installations realize savings in timeand money, but the citing of non-DoD sources may be perceived as more credible by regulatory agencies and the general public.

! Public involvement in natural resource management.

Collaboration with the public in matters of natural areas conservation and endangered species protection is a good way for DoD to foster a sense of cooperation and trust between civilian and military personnel. 
Involving the public not only has the potential to bring even more outside expertise to bear on management decisions, but interested and concerned citizens may serve as a source of volunteer labor for management activities requiring more staff than installations have available to complete those tasks.

\section{Monitoring}

Managers should monitor the effects of their management practices on the communities or thefeatures of interest. F or the purpose of long-term monitoring, standard sampling methods should be developed and used. Being able to quantify improvement or degradation of habitats over time can be important to making management decisions, as well as evaluating management practices. Methods as simple as establishing permanent plots or grids are useful for repeated surveys. These surveys should be done at regular intervals and at the same time of the year to decrease the chance of bias from one year to the next. Aerial photographs can be used to monitor landscape and community changes over time. Keeping accurate records of land use is also important (e.g., detailed notes of fire occurrence and species response, as well as dearcutting techniques, etc.).

\section{Community Quality}

Managers at Eglin AF B, FL, have devel oped the Ecological Tier System to classify community quality (Department of the Air F orce 1993). This system has also been used recently at Camp Blanding, FL (FNAI and TNC 1995). Determination of community quality has obvious benefits for conservation planning. Low quality communities do not merit the same conservation status as higher quality communities and therefore should be treated differently in terms of protection, restoration efforts, and allowable land uses. Use of a quality ranking system for management purposes can assure that protection priority is given to the highest quality commu-nities, because these are the best examples of natural species assemblages and other community attributes. Although position in the landscape relative to other communities may also be important in assessing priority. The use of this system can assure that restoration activities are used for communities that have the potential to become high quality with minimum restoration efforts. Restoration of such communities can enhance habitats that support TES. Similarly, use of a quality ranking system can ensure that efforts are not wasted in the restoration of low quality communities. Finally, plant communities on installations are subject to multiple land uses, and use of a quality ranking system in combination with an assessment of impacts of various land uses can allow managers to determine which activities are appropriate in which communities, 
based on quality. The ranking system developed for Eglin AFB, FL, has been adapted for this report, with descriptive names given to each community quality type:

TYPE I - High-quality community: "Portions of vegetative communities which are in or closely approximate their natural state.... These areas have experienced relatively few disruptive events. Examples areareas of old growth or relatively undisturbed vegetation. Management activities should bepredominantly in the maintenance category, utilizing methods that mimic natural formative forces such as prescribed fire" (Department of the Air Force 1993).

TYPE II - Intermediate quality community: "Portions of vegetative communities that still retain a good representation and distribution of associated species and which have been exposed to moderate amounts and intensities of disruptive events... These are areas where ecosystem function and viability can be restored through careful, responsiblemanagement. Management direction will integrate appropriate management activities to accomplish restoration and maintenance objectives. Restoration activities may include practices that will accelerate change in the desired direction (i.e., use of herbicides, and/or mechanical methods of hardwood control, supplemental planting of Iongleaf seedlings)" (Department of the Air F orce 1993).

TYPE III - Moderately low quality community: "Portions of vegetative communities that do not retain a good representation and distribution of associated species and which have been exposed to severe amounts and intensities of disruptive events... These are areas where restoration of ecosystem function and viability might be possible, but would require significant and intensive management commitment over extended periods of time. Depending on land-use priorities, management direction may encourage a return to a more natural vegetative association over the long term and/or may include intensive use of traditional management techniques" (Department of the Air Force 1993).

TYPE IV - Lowest quality community: “...sites that either will not be or are not capable of being restored under any likely realisticscenario because of dedicated land use. Type IV areas include cleared test ranges, sewage disposal spray fields, urban areas, main roads, designated clay pits, power line rights-of-way, and possibly some wildland interface areas" (Department of the Air Force 1993).

In addition to giving a quality ranking to a community based on naturalness, managers may wish to use other parameters to determine what kind of activities 
should occur in communities, and which communities should be protected from various activities. For example, presence of rare species, overall diversity, unusual species combinations, and diverse physical features (e.g., soil types, hydrologic regimes, and topographic situations) should be considered. Some systems consider all of these parameters and give a site a ranking based on them (e.g., White 1978). Computer and mathematical models can aid in assessing habitat quality. Onesuch model was developed by Rossi and Kuitunen (1996) to use in the early stages of land use planning. This model generates a habitat value (HV) index for each area and uses these to rank patches according to their conservation value in order to assess and compare them, thereby minimizing biological damage that results from land use decisions. This index is calculated on the basis of all the species present in the patch (vascular plants, mammals, birds, amphibians, and reptiles); threat categories, in which all species are classified according to their regional degree of threat; and the likelihood of each species occupying spacific habitats, determined from available literature. The objectives of this model were to formulate an assessment procedure, while minimizing fieldwork and avoiding errors due to species remaining unnoticed in the field (Rossi and Kuitunen 1996). 


\section{References}

Abrahamson, W. G., and Abrahamson, J .R. 1996. "Effects of low-intensity winter fire on longundisturbed Florida sand pine scrub." Natural Areas J ournal. 16:171-183.

Abrahamson, W. G., and Hartnett, D. C. 1990. "Pine flatwoods and dry prairies." In R.L. Meyers, and J .J . E wel (eds.), E cosystems of Florida. University of Central Florida Press, Orlando.

Abrahamson, W.G., J ohnson, A.F., Layne, J .N. and Peroni, P.A. 1984. "Vegetation of the Archbold Botanical Station, Florida: an example of the southern Lake Wales ridge." Florida Scientist, 47:209-250.

Alford, R. A., 1980. "Population structure of Gopherus polyphemus in northern Florida." J ournal of Herpetology, 14(2):177-182.

Anderson, R.C., and Menges, E.S. 1997. "Effects of fire on sandhill herbs: Nutrients, mycorrhizae, and biomass allocation." Americal J ournal of Botany, 84(7): 938-948.

Auffenberg, W. And Franz, R. 1982. "The status and distribution of the gopher tortoise (Gopherus pol yphemus)." In R.B. Bury (ed.) N orth American Tortoi ses: Conservation and Ecology. USFWS Wild. Res. Rept.12. pp.95-126.

Axelrod, D. I., 1958. "Evolution of the Madro-Tertiary geoflora," Botanical Review, 24: 432-509.

Berry, D. M. and Menges, E. S. 1995. "Post-fire changes in resource limitation of Florida scrub plants." Abstracts, Conferenceon fire effects on threatened and endangered species and habitats, Nov. 13 - 16 1995, p. 46.

Boyle, S. R., Schmalzer, P.A., and Adrian, F.W. 1998. "Methods for restoring long-unburned Florida oak-palmetto scrub using mechanical cutting and prescribed burning." Abstract of presented poster in: Program and Abstracts of the 21st Tall Timbers Fire Ecology Conference p.33.

Breininger, D.R., and Schmalzer, P.A. 1990. "Effects of fire and disturbance on plants and birds in a Florida oak/palmetto scrub community." American Midland Naturalist, 123:64-74.

Breininger, D. R., 1992. Habitat mode for the Florida scrub jay on Kennedy Space Center. NASA Tech. Memo. 107543. J ohn F. Kennedy Space Center, Florida.

Breininger, D. R., Larson, V. L., Duncan, B. W., Smith, R. B., Oddy, D., M., and Goodchild, M. F. 1995. "Landscape patterns of Florida scrub jay habitat use and demographic success." Conservation Biology, 9:1442-1453. 
Breininger, D. R., Larson, V.L., Schaub, R., Duncan, B. W., Schmalzer, P.A., Oddy, D. M., Smith, R.B., Adrian, F., and Hill, H. 1996. A conservation strategy for the Florida scrub jay on J ohn F. Kennedy Space Center / Merritt Island National Wildlife Refuge: An initial scientific basis for recovery. NASA Technical Manual 111676. National Aeronautics and Space Administration, J ohn F. Kennedy Space Center, Florida.

Burst, Tom. 1988. "The Fish and Wildlife Section of the Natural Resource Management Plan for the Naval Air Station, Cecil Field, FL."

Burst, Tom. 1995a. "The Fish and Wildlife Section of the Natural Resource Management Plan for the Naval Air Station, Pensacola, FL."

Burst, Tom. 1995b. "The Fish and Wildlife Section of the Natural Resource Management Plan for the Naval Air Station, Whiting Field, FL."

Campbell, H. W., 1992. in Rare and Endangered Biota of Florida, Volume III Amphibians and Reptiles, Paul E. Moler (ed.) University Press of Florida, Gainesville, FL. pp. 150-153.

Christensen, N. L. 1985. "Shrubland fire regimes and their evolutionary consequences." I n: Pickett, S.T.A. and White, P.S. (Eds.) The ecol ogy of natural disturbanceand patch dynamics, Academic Press, San Diego, CA. pp. 85-100.

Christensen, N. L. 1988. "Vegetation of the Southeastern Coastal Plain." In: M. G. Barbour and W. D. Billings (eds.). North American Terrestrial Vegetation. Cambridge University Press, New York. pp 317-363.

Christman, S. P. 1995. Management of Florida Scrub at Camp Blanding, Clay County, Florida. Report prepared for Camp Blanding Training Site, Dept. of Military Affairs, Florida Army National Guard.

Christman, S. P. and J udd, W. S. 1990. "Notes on plants endemic to Florida scrub." Florida Scientist 53(1):52-73.

Coile, N. C. and Shilling, D. G. 1993. "Cogongrass, I mperata cylindrica (L.) Beauv.: A good grass gone bad!" Botany Circular No. 28, Florida Dept. Agric. \& Consumer Services, Division of Plant Industry, Gainesville, FL.

Colvin, D.L., Gaffney, J ., and Shilling, D. G. 1994. "Cogongrass (Imperata cylindrica (L.) Beauv.) Biology, ecology and control in Florida." U niversity of Florida, I nstitute of F ood and Agricultural Services, Gainsville, FL. Circular SS-AGR-52, Weeds in the Sunshine Series. 4 p.

Cox, A. C., and Roberts, R. E. 1995. "Resource management of scrub listed species." Abstracts, Conference on fire effects on threatened and endangered species and habitats, Nov. 13 - 16 1995, p. 47.

Cox, J . A. 1984. "Conservation and ecology of the Florida scrub jay." Ph.D dissertation, University of Florida, Gainseville. 
DeGange, A. R., Fitzpatrick, J . W., Layne, J . M., and Woolfenden, G. E. 1989. "Acorn harvesting by Florida scrub jays." Ecology, (47):348-56.

Deyrup, M. and Franz, R. (Editors) 1994. Rare and Endangered Biota of Florida Volume 4: Invertebrates. University Press of Florida, Gainesville, FL.

Diemer, J . E., 1992. "Home range movements of the tortoise Gopherus polyphemus in northern Florida." J ournal of Herpetology, 26(2):158-165.

Department of the Air Force. 1993. "Natural Resources Management Plan, Eglin Air Force Base, 1993-1997." Eglin Air Force Base, FL.

Doren, R.F., Richardson, D.R., and Roberts, R.E. 1987. "Prescribed burning in the sand pine scrub community: Yamato Scrub, a test case." Florida Scientist 50:184-192.

Douglass, J . F. 1976. "The mating system of the gopher tortoise in southern Florida." M.S. Thesis, University of Southern Florida. OCLC\#3454574.

Dreschel, A. R., Smith, R. B., and Breininger, D. R., 1990. "Florida scrub jay mortality on roadsides." Florida Field Naturalist 18(4):82-83.

Duever, L.C. 1989. "Research priorities for the preservation, management, and restoration of wiregrass ecosystems." Natural Areas J ournal 9(4):214-21.

Duncan, B. W., Breininger, D. R., Schmalzer, P. A., and Larson, V. L., 1995. "Validating a Florida scrub jay habitat suitability model, using demography data on Kennedy Space Center." Photogrammetric Engineering and Remote Sensing 56:1361-1370.

Dunning, J . B. 1993. "Bachman's sparrow." In A. Poole, P. Stettenheim, and F. Gill, eds. Thebirds of North America, No. 38. The Academy of Natural Sciences, Washington, DC.

Environmental Services \& Permitting, Inc. 1990. "Summary Endangered Species Survey at the J acksonville, Florida Naval Complex."

Florida Department of Commerce. 1998. Population Statistics. World Wide Web URL: http://www.floridabusiness.com/frames.html

Florida Natural Areas Inventory (FNAI ). 1988. Survey of Pensacola Naval Air Station and Outlying Field Bronson for Rare and Endangered Plants. Final Report to the Florida Game and Fresh Water Fish Commission, Contract No. W311, Tallahassee, Florida.

FNAI and Florida Department of Natural Resources (FDNR). 1990. Guide to the natural communities of Florida. FNAI and FDNR, Tallahassee, Florida.

FNAI. 1994a. Biological Survey of Tyndall Air ForceBase. Final Report. FNAI Tallahassee, Florida.

FNAI. 1994b. Eglin Natural Communities Survey: Year One Report. Tallahassee, Florida. 
FNAI and TNC. 1995. Camp Blanding Training Site Natural Community Survey, Final Report. Contract number ENV 1.

FNAI. 1997. Natural Community Survey of Naval Air Station Whiting Field and Outlying Landing Field, Final Report. FNAI, Tallahassee, Florida.

FNAI. 1998. Information from the FNAI Database sent on 23 February, 1998 by Barbara Lenczewski, Environmental Reviewer, Florida Natural Areas Inventory Tallahassee, Florida.

F rost, C. 1993. "Four centuries of changing landscape patterns in the longleaf pine ecosystem." In S. M. Hermann (ed.), Proceedings of the Tall Timbers Fire Ecology Conference, No. 18, The Longleaf PineE cosystem: ecol ogy, restoration and management, pp. 17-44. Tall Timbers Research Station, Tallahassee, FL.

Frost, C. C., Walker, J ., and Peet, R. K. 1986. "Fire dependent savannas of the southeast: Original extent, preservtion status and management problems," in D.L. Kulhavey and R.N. Connor (eds), Wilderness and Natural Areas in theEastern United States: A Management Challenge. Center for applied studies, School of Forestry, Stephen F. Austin State University, Nacogdoches, TX.

Gehlhausen, S., M. G. Harper, and A. Trame. 1998. Management of Maritime Communities for Threatened and Endangered Species, USACERL Technical Report 98/79 (USACERL, J une).

Godfrey, R. K., and Wooten, J . W. 1979. Aquatic and Wetland Plants of the Southeastern United States, Monocotyledons. The University of Georgia Press, Athens.

Godfrey, R. K., and Wooten, J. W. 1981. Aquatic and Wetland Plants of the Southeastern United States, Dicotyl edons. The University of Georgia Press, Athens.

Godley, J . S. 1992. "Gopher Frog Rana capito Le Conte," in Rareand Endangered Biota ofF lorida, Volume III Amphibians and Reptiles, Paul E. Moler (ed.) University Press of Florida, Gainesville, FL. pp. 15-19.

Greenberg, C. H., Crownover, S. H., and Gordon, D.R. 1997. "Roadside soils: a corridor for invasion of xeric scrub by nonindiginous plants." Natural Areas J ournal 17:99-109.

Greenberg, C. H., Neary, D. G., Harris, L. D., and Linda, S. P. 1995. "Vegetation recovery following high-intensity wildfire and silvicultural treatments in sand pine scrub." American Midland Naturalist 133:149-163.

Harper, M., Trame, A. M., Fischer, R. A., and Martin, C. O. 1998. Management of Longl eaf Pine Woodlands for Threatened and Endangered Species. USACERL Technical Report 98/21 (USACERL, December).

Harper, M., Trame, A. M., and Hohmann, M. G. 1998. Management of Herbaceous Seeps and Wet Savannas for Threatened and Endangered Species. USACERL Technical Report 98/70 (USACERL, April). 
Hawkes, C. V., and Menges, E. S. 1995. "Density and seed production of a Florida endemic, Polygonela basiramia, in relation to time since fire and open sand." American Midland Naturalist. 133:138-148.

Hawkes, C. V., and Menges, E. S. 1996. "The relationship between open space and fire for species in a xeric Florida shrubland." Bulletin of theTorrey Botanical Club. 123(2):81-92.

Hokit, G. D., Stith, B. M., and Branch, L. C. In Press. "Effects of landscape structure in Florida scrub: A population perspective." Ecological Applications.

Howie, S. 1994. Draft version of Species of Concern on U.S. Air Force Lands: A Base-Specific Handbook for Avon Park Air Force Range, Pilot Project. Department of the Air Force.

Humphrey, S. R. (E ditor). 1992. "Florida Mouse," in Rareand Endangered Biota of Florida, Volume I. Mammals, University Press of Florida, Gainsville, FL. pp.250-263.

J ohnson, A. F., and Abrahamson, W. G. 1990. "A note on the fire responses of species in rosemary scrubs on the southern Lake Wales Ridge." Florida Scientist 53:138-143.

J ohnson, A. F., Muller, J . W., and Bettinger, K. A. 1992. An Assessment of Florida's remaining coastal upland natural communities: Pandhandle FNAI, Tallahassee, FL.

J ohnson, A. F. 1993. "Population Status Survey of Polygonella macrophylla Small." Florida Natural Areas Inventory, Tallahassee, Florida.

J ordan, R.A., Wheaton, K.S., and Wei her, W. M. 1995. Integrated endangered species management recommendations for army installations in the southeastern United States: Assessment of army-widemanagement guidel ines for thered-cockaded woodpecker and associated endangered, threatened and candidate species. Final draft report prepared for the Natural Resources Division of the U.S. Army Construction Engineering and Research Laboratories, Champaign, IL. The Nature Conservancy, Southeast Regional Office, Chapel Hill, North Carolina.

Keech, J . J . and G. M. Byram. 1968. A drought index for forest fire control. USDA Forest Service Research Paper SE-38. Southeastern Forest Experiment Station, Asheville, NC. 32 pp.

Kenner, W. J . 1994. "Sand pine scrub restoration: An alternative to high-intensity fire (Florida)." Restoration and Management Notes 12(1):83.

Kral, R. 1983. A report on somerare, threatened, or endangered forest-related vascular plants of the South. U.S. Department of Agriculture, Forest Service, Tech. Pub. R8-TP2, Atlanta, Georgia.

Labat-Anderson Incorporated. 1994. “Threatened and Endangered Species Survey, Hurlburt Field, Florida," Final Report. LABAT-ANDERSON Incorporated, Bellevue, Florida.

Landers, J . L., Garner, J . A., and M CRae, W. A. 1980. "Reproduction of gopher tortoises (Gopherus polyphemus) in southwestern Georgia." Herpetol ogica 36:353-361. 
Langeland, K. 1990. "Exotic Woody Plant Control." Circular 868, Florida Cooperative Extension Service, Institute of Food and Agricultural Sciences, U niversity of Florida and Exotic Plant Pest Control Council, Gainesville, FL.

Langeland and Stocker 1997, "Control of N on-N ativePlants in Natural Areas of Florida." Publication number SP242.IFAS. University of Florida, Gainesville, FL.

Layne, J . N. and J ackson, R.J . 1994. Burrow use by the Florida mouse (Podomys floridanus) in South-central Florida. American Midland Naturalist 131:17-23.

Leblond, R. J . Fussell, J . O., and Braswell, A. L. 1994. "Inventory of the rare species, natural communities, and critical areas of the Camp Lejeune Marine Corps Base, North Carolina." North Carolina Natural Heritage Program, DPR, Dept. Environment, Health, and Natural Resources, Raleigh, North Carolina.

Lohoefener, R. And Lohmeier, L. 1981. "Comparison of gopher tortoise (Gopherus polyphemus) habitats in young slash pine and old longleaf pine areas of southern Missisippi," J ournal of Herpetol ogy, 15:239-242.

Lohoefener, R. And Lohmeier, L. 1984. "The status of Gopherus polyphemus west of the Tombigee and Mobile Rivers," unpublished report submitted to the US Fish and Wildlife Service, 104 pp.

Martin, C.O., Fischer, R.A., Harper, M.G., Tazik, D.J ., and Trame, A-M. 1996, Regional Strategies fir Managing Threatened and Endangered Species Habitat: A Concept Plan and Status Report. Technical Report SERDP-96-1 (WES).

McCoy, E. D. and Mushinsky, H. R. 1992. "Studying a species in decline: Changes in the populations of the gopher tortoise on federal lands in Florida." Biological Sciences (2)116-124.

McCoy, E. D. and Mushinsky, H. R. 1994. "Effects of fragmentation on the richness of vertebrates in the Florida scrub habitat." Ecology 75(2):446-457.

McGowen, K. J . and Woolfenden, G. E., 1989. "A sentinal system in the Florida scrub jay." Animal Behavior, 37:1000-1006.

McRae, W.A., Landers, J .L. and Garner, J .A. 1981. "Movement patterns and home range of the gopher tortoise," American Midland Naturalist, 106:165-179.

Means, D. B. and Grow, G. 1985. "The Endangered Longleaf Pine Community." ENFO Newsletter 85:1-12.

Melton, M. 1989. "The Keech/Bryam Drought Index: A guide to fire conditions and suppression problems." Fire Management Notes 50(4):30-34.

Menges, E.S., and Hawkes, C.V. 1998. "Interactive effects of fire and microhabitat on plants of Florida scrub". Ecological Applications 8(4): 935-946. 
Menges, E.S., and Kimmich, J . 1996. "Microhabitat and time since fire: Effects on demography of Eryngi um cunei fol ium (Apiaceae), a Florida scrub endemic plant." American J ournal of Botany, 83(2): 185-191.

Menges, E.S., and Kohfeldt, N. 1995. "Life history strategies of Florida scrub plants in relation to fire." Bulletin of the Torrey Botanical Club, 122(4):282-297.

Mills, L.S., M.E. Soule and D.F. Doak. 1993. "The Keystone- Species Concept in Ecology and Conservation," Bioscience vol 43, no. 4, pp. 219- 224.

Mitchell, W. A., 1997. Species Profile: Florida scrub jay (Aphelocoma coerulescens) on military installations in the southeastern United States. Technial report SERDP-97-11, US Army Corps of Engineers Waterways Experiment Station (WES), Vicksburg, MS.

Moler, P. E. 1992. "Eastern Indigo Snake, Drymarchon corais couperi." pp. 181-186 In: P. E. Moler (ed.). Rare and Endangered Biota of Florida. Vol. III. Amphi bians and Reptiles. Univ. Presses of Florida, Gainesville.

Mushinsky, H.R. and McCoy, E.D., 1995. Vertebratespecies composition of selected scrub islands on thelakeWales Ridge of central Florida. Non-gameWildlife Program Project Report No.GFC-87149, Florida Game and Fresh Water Fish Commission; Tallahassee, Florida.

Myers, R. L. 1990. "Scrub and high pine." pp 150-193 in R. L. Myers, and J .J . Ewel (eds.), E cosystems of Florida. University of Central Florida Press, Orlando, Florida.

Noss, R. F., LaRoe III, E. T., and Scott, J . M. 1992. Endangered Ecosystems of The United States: A Preliminary Assessment of Loss and Degradation.Downloaded from the U.S. Geological Survey, Biological Resources Division website: http://biology.usgs.gov/pubs/ecosys.htm.

Ostertag, R., and Menges, E.S. 1994. "Patterns of reproductive effort with time since last fire in Florida scrub plants." J ournal of Vegetation Science 5:303-310.

Parker, V. T. 1989. Maximizing vegetation responceon management burns by identifying fireregi mes. USDA Forest Service, Gen Techn. Rep. PSW-109.

Quintana-Ascencio, P.F. and E.S. Menges. 1996. "I nferring Metapopulation Dynamics from PatchLevel Incidence of F lorida Scrub Plants," Conservation Biology, vol 10, no. 4, pp. 1210- 1219.

Richardson, D. R. 1989. "The sand pine scrub community: an annotated bibliography." Florida Scientist 52:65-93.

Rossi, E., and Kuitnen, M. 1996. "Ranking of habitats for the assessment of ecological impact in land use planning." Biological Conservation. 77(2):227-234. 
Russo, M. J ., Sorrie, B. A., Van Eerden, B., and Hippensteel, P. E. 1993. Rare and Endangered Plant Survey and Natural Area Inventory for Fort Bragg and Camp Mackall Military Reservations, North Carolina. The Nature Conservancy, Carrboro, North Carolina and North Carolina Natural Heritage Program, DPR, North Carolina.

Schmalzer, P. A., Breininger, D. R., Adrian, F. W., Schaub, R., and Duncan, B. W. 1994. Development and implementation of a scrub habitat compensation plan for Kennedy Space Center. Technical Memorandum 109202, National Aeronautics and Space Agency, Kennedy Space Center, FL.

Schmalzer, P. A., and Hinkle, C.R. 1991. Dynamics of vegetation and soils of oak/ saw pal metto scrub after fire: observations from permanent transects. NASA Technical Memorandum 103817. National Aeronautics and Space Agency, Kennedy Space Center, FL.

Schmalzer, P. A., and Hinkle, C.R. 1992. "Recovery of oak-saw palmetto scrub after fire." Castanea, 57(3): 158-173.

Small, J . K. 1972. Manual of the Southeastern Flora, Part Two (Facsimile Reprint of the 1933 Edition). Hafner Publishing Company, New York.

Stout, I. J . and Marion, W. R. 1993. "Pine flatwoods and xeric pine forests of the Southern (lower) Coastal Plain." In W. H. Martin, S. G. Boyce, and A. C. Echternacht (eds.), Biodiversity of the Southeastern United States, pp. 373-446. J ohn Wiley \& Sons, Inc., New York.

Terhune, F. W. (ed.). 1982. 1982 Florida Statistical Abstract. University of Florida Press, Gainesville, FL.

The Nature Conservancy. 1994. Integrated Natural Resource Management Plan, Avon Park Air Force Range, FL, Phase I, Final Report, LakeWales, FL.

TheNature Conservancy. 1995. Fort Stewart Inventory, Final Report. U.S. Department of Defense, Dept. of the Army, Headquarters 24th Mechanized Division, Ft. Stewart, GA.

Trame, A. M., and Harper, M. 1997. Potential Military Effects on Selected Plant Communities in the Southeastern United States. USACERL Technical Report 97/115. (USACERL).

Trame, A. M., and Tazik, D. J . 1995. The I mplications of E cosystem Management for Threatened and Endangered Species Conservation by the U.S. Army. USACERL Technical Report 95/27. (USACERL).

United States Fish and Wildlife Service (USFWS). 1982. Eastern Indigo Snake Recovery Plan. USFWS, Atlanta, GA.

United States Fish and WildlifeService (USFWS). 1983. Chapman's R hododendron Recovery Plan. USFWS, Atlanta, GA. 
United States Fish and Wildlife Service (USFWS). 1990a. Gopher TortoiseRecovery Plan. USFWS, Atlanta, GA.

United States Fish and Wildlife Service (USFWS). 1990b. Florida Scrub J ay Recovery Plan. USFWS, Atlanta, GA.

United States Fish and Wildlife Service (USFWS). 1995. "Draft Recovery plan for nineteen central Florida scrub and high pineland plants (revised)." U.S. Fish and Wildlife Service, Atlanta, GA.

United States Fish and Wildlife Service (USFWS). 1998. "Multi-Species recovery plan for the threatened and endangered species of South Florida." Technical Agency Draft. Atlanta, Georgia.

Ward, D. B. 1979. Rareand Endangered Biota of Florida, VolumeFive, Plants. University Presses of Florida, Gainesville.

Wharton, C. H. 1978. The Natural Environments of Georgia. Geologic and Water Resources Division and Resource Planning Section, Office of Planning and Research, Georgia Department of Natural Resources, Atlanta, Georgia.

White, J . 1978. Illinois Natural Areas Inventory, Technical Report, Vol I: Survey Methods and Results. Illinois Natural Areas Inventory, Urbana.

Woolfenden, G. E., 1974. "Nesting and survival in a population of Florida scrub jays." Living Bird, (12):25-49.

Woolfenden, G. E., and Fitzpatrick, J . W. 1984. TheF Iorida ScrubJ ay: Demography of a cooperative breeding bird. Princeton University Press, Princeton, NJ .

Wool fenden, G. E., and Fitzpatrick, J . W. 1991. "F lorida scrub jay ecology and conservation," in Bird Population Studies (C.M. Perrins, J .D. Lebreton and G.J.M. Hirons, eds.) Oxford University Pres, New York. pp. 542-565. 


\section{Professional Communications}

Cruize, Lloyd, Natural Resourse Manager, NAS, Cecil Field, J acksonville, FL, 29 J anuary 1998.

Deyrup, Mark, Entomologist, Archbold Biological Station, FL, 14 J anuary 1998.

Gordon, Doria, State E cologist for the Florida region of The Nature Conservancy, 5 F ebruary 1996.

Hawkes, Christine, GraduateStudent, Department of Biology, University of Pennsylvania, 21 May, 1998.

Huffman, Mary, Program Director for the Lake Wales Ridge Program, The Nature Conservancy, Lake Wales Ridge, FL, 12 March 1998.

Lowery, Laura, USFS Biologist for the Ocala National Forest, Lake George Ranger District, Silver Springs, FL, 25 February 1998.

Menges, Eric, Senior Research Biologist, Archbold Biological Station, FL, 5 February 1996.

McCoy, Earl D. Professor, Department of Biology, University of South Florida, Tampa,FL, 29J une 1998.

Morris, Larry, Camp Blanding, FL, J une 1998.

Orzell, J im, Botanist, Avon Park Air Force Range, FL, 26 J une 1998.

Roberts, Dick, Biologist, Region 5 Office, Florida Park Service, Hobestown, FL, 11 March 1998.

Schmalzer, Paul, Senior Field E cologist, Dynamac Corporation, DYN-2, Kennedy Space Center, FL, 12 May 1998.

Weakley, A., Southeast Regional Ecologist, Southeast Regional Office, The Nature Conservancy, Raleigh, NC, 12 May 1995. 


\section{Abbreviations and Acronyms}

\begin{tabular}{|c|c|}
\hline$A E C$ & Army Environmental Center \\
\hline$A F B$ & Air Force Base \\
\hline AFR & Air Force Range \\
\hline ATV & All Terrain Vehicle \\
\hline DA & Department of the Army \\
\hline DAID & Delayed Aerial Incendiary Device \\
\hline DoD & Department of Defense \\
\hline EL & Environmental Laboratory \\
\hline EOR & Element of Occurrence Record \\
\hline ESA & Endangered Species Act \\
\hline FDNR & Florida Department of Natural Resources \\
\hline FNAI & Florida Natural Areas Inventory \\
\hline FORSCOM & U. S. Army Forces Command \\
\hline HQDA & Headquarters, Department of the Army \\
\hline HV & Habitat Value \\
\hline INRMP & Integrated Natural Resources Management Planning \\
\hline ITAM & Integrated Training and Management \\
\hline LCTA & Land Condition Trend Analysis \\
\hline LL & Land Management Laboratory \\
\hline LRAM & Land Rehabilitation and Maintenance Program \\
\hline
\end{tabular}




$\begin{array}{ll}\text { NAS } & \text { Naval Air Station } \\ \text { NASA } & \text { National Aeronautics and Space Administration } \\ \text { NFFL } & \text { National Forest Fire Laboratory } \\ \text { NHP } & \text { Natural Heritage Program } \\ \text { NRD } & \text { Natural Resources Division } \\ \text { SOC } & \text { Species of concern } \\ \text { SSC } & \text { Species of Special Concern } \\ \text { SERDP } & \text { Strategic Environmental Research and Development Program } \\ \text { TES } & \text { Threatened and Endangered Species } \\ \text { TNC } & \text { The Nature Conservancy } \\ \text { USACERL } & \text { U.S. Army Construction Engineering Research Laboratories } \\ \text { USFS } & \text { U.S. Forest Service } \\ \text { USFWS } & \text { U.S. Fish and Wildlife Service } \\ \text { WES } & \text { U.S. Army Engineer Waterways Experiment Station } \\ & \end{array}$




\section{Distribution}

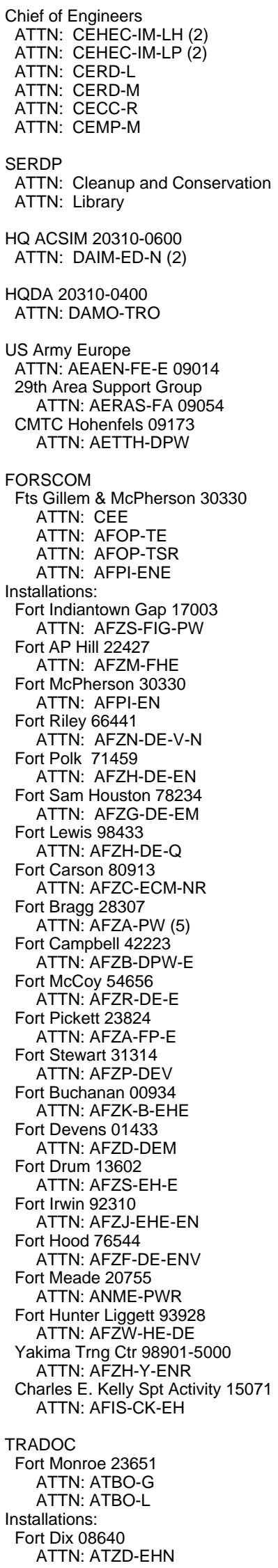

Fort Lee 23801

ATTN: ATZM-EPE

Fort Jackson 29207

ATTN: ATZJ-PWN

Fort Gordon 30905

ATTN: ATZH-DIE

Fort Benning 31905

ATTN: ATZB-PWN

Fort Hamilton 11252

ATTN: ATZD-FHE

Fort McClellan 36205

ATTN: ATZN-EM

Fort Rucker 36362 ATTN: ATZQ-DPW-EN

Fort Leonard Wood 64573

ATTN: ATZT-DPW-EE

Fort Leavenworth 66027

ATTN: ATZL-GCE

Fort Bliss 79916

ATTN: ATZC-DOE

Fort Monroe 23651

ATTN: ATZG-ISE

Carlisle Barracks 17013

ATTN: ATZE-DPW-E

Fort Eustis 23604 ATTN: ATZF-PWE

Fort Chaffee 72905 ATTN: ATZR-ZF

Fort Sill 73503

ATTN: ATZR-B

Fort Huachuca 85613 ATTN: ATZS-EHB

Fort Knox 40121 ATTN: ATZK-PWE

Fort Story 23459 ATTN: ATZF-EMI-S

US Air Force Command ATTN: Envr/Natural Res Ofc Andrews AFB 20031 Wright-Patterson AFB 45433

Randolph AFB 78150

Maxwell AFB 36112

Elmendorf AFB 99506

Scott AFB 62225

Hickam AFB 96853

Peterson AFB 80914

Bolling AFB 20332

US Air Force Air Combat Command Avon Park AF Range, FL 33825-5700 ATTN: 6 CSS/CEN

Beale AFB, CA 95903-1708 ATTN: 9 CES/CEV

Barksdale AFB, LA 71110-2078 ATTN: 2 CES/CEVC

Davis-Monthan AFB, AZ 85707-3920 ATTN: 355 CES/CEV

Dyess AFB, TX 79607-1670 ATTN: 7 CES/CEVA

Ellsworth AFB, SD 57706-5000 ATTN: 28 CES/CEV

Holloman AFB, NM 88330-8458 ATTN: 49 CES/CEV

Langley AFB, VA 23665-2377 ATTN: 1 CES/CEV

Little Rock AFB, AR 72099-5154 ATTN: 314 CES/CEV

MacDill AFB, FL 33621-5207 ATTN: 6 CES/CEV

Cannon AFB, NM 88103-5136 ATTN: 27 CES/CEV

Minot AFB, ND 58705-5006 ATTN: 5 CES/CEV

Moody AFB, GA 31699-1707 ATTN: 347 CES/CEV

Nellis AFB, NV 89191-6546 ATTN: WTC/EVR

Offutt AFB, NE 68113-4019 ATTN: 55 CES/CEV

Pope AFB, NC 28308-2890 ATTN: 23 CES/CEV

Mountain Home AFB, ID 83648-5442 ATTN: 366 CES/CEV
Seymour Johnson AFB, NC 27531-2355 ATTN: 4 CES/CEV

Shaw AFB, SC 29152-5123 ATTN: 20 CES/CEV

Whiteman AFB, MO 65305-5060 ATTN: 509 CES/CEV

HQ US Army - Pacific (USARPAC)

DCSENGR - ATTN: APEN-IV

ATTN: APOP-TR

Fort Shafter, HI 96858

Fort Richardson, AK 99505

Fort Wainright, AK 99703

Fort Greely, AK 98733

USAMC Instal \& Srvc Activity ATTN: AMXEN-U 61299

US Army Armament, Munitions and Chemical Cmd

ATTN: AMSMC-ENR

ATTN: AMSMC-EQC

US Army Aviation and Troop Cmd ATTN: SATAI-A

US Army Comm-Elec Cmd ATTN: AMSEL-SF-REE

US Army Depot System Cmd ATTN: AMSDS-IN-E

US Army Missile Cmd ATTN: AMSMI-RA

US Army Tank-Automotive Cmd ATTN: AMSTA-XEM/AMSTA-XA

US Army Test \& Eval Cmd ATTN: AMSTE-EQ

White Sands Missile Range ATTN: STEWS-ES-E

Charles Melvin Price Spt Ctr ATTN: SATAS-F

US Army Arm. Res Devel \& Engr Ctr ATTN: AMSTA-AR-ISE-UL

US Army Natick Res Devel \& Engr Ctr ATTN: SATNC-ZSN

Pine Bluff Arsenal ATTN: SMCPB-EMB

Rock Island Arsenal ATTN: SMCRI-PWB ATTN: AMSCM-EHR

Watervliet Arsenal ATTN: SMCWV-PW

US Army Dugway Proving Ground ATTN: STEDP-EPO-CP

US Army Jefferson Proving Ground ATTN: STEJP-EH-R

US Army Yuma Proving Ground ATTN: STEYP-ES-E

Anniston Army Depot ATTN: SDSAN-DPW-PED

Blue Grass Army Depot ATTN: SDSBG-EN

Red River Army Depot ATTN: SDSRR-OE

Sacramento Army Depot ATTN: SDSSA-EL-MO

Sierra Army Depot ATTN: SDSSI-ENV

Tobyhanna Army Depot ATTN: SDSTO-EM

US Army Depot-Hawthorne ATTN: SMCHW-ORE

Pueblo Army Depot Activity ATTN: SDSTE-PU-SE

Savanna Army Depot Activity ATTN: SDSLE-VA

Seneca Army Depot Activity ATTN: SDSTO-SEI-PE Umatilla Army Depot Acitivty ATTN: SDSTE-UAS-EVE

McAlester Army Ammunition Plant ATTN: SMCMC-DEL

Holston Army Ammunition Plant ATTN: SMCHO-EN

Indiana Army Ammunition Plant ATTN: SMCIN-EN 
lowa Army Ammunition Plant ATTN: SMCIO-PPE

Kansas Army Ammunition Plant ATTN: SMCKA-OR

Lake City Army Ammunition Plant ATTN: SMCLC-EN

Lone Star Army Ammunition Plant ATTN: SMCLS-SEE

Longhorn/Louisiana Army Ammo Plant ATTN: SMCLO-EN

Milan Army Ammunition Plant ATTN: SMCMI-IO

Mississippi Army Ammunition Plant ATTN: SMCMS-CA

Newport Army Ammunition Plant ATTN: SMCNE-EN

Radford Army Ammunition Plant ATTN: SMCRA-OR

Sunflower Army Ammuniton Plant ATTN: SMCSU-EN

US Army Aberdeen Proving Ground Spt Acty ATTN: STEAP-FE-G/STEAP-SH-ER ATTN: AMSTE-EQ

Redstone Arsenal Spt Activity ATTN: AMSMI-RA-DPW-MP-PR

US Army TACOM Spt Activity-Selfridge ATTN: AMSTA-CYE

Lima Army Tank Plant

ATTN: DCMDM-PDM

US Army Garrison-Fort Monmouth ATTN: SELFM-PW

Alabama Army Ammunition Plant ATTN: SMCAL

Badger Army Ammunition Plant ATTN: SMCBA-OR

Cornhusker Army Ammunition Plant ATTN: SMCCO

Joliet Army Ammunition Plant ATTN: SIOJO-OR

Ravenna Army Ammunition Plant ATTN: SMCRV-CR

Riverbank Army Ammunition Plant ATTN: SMCRB-CR

St. Louis Army Ammunition Plant ATTN: SATAI-A

Twin Cities Army Ammunition Plant ATTN: SMCTC-EN

Volunteer Army Ammunition Plant ATTN: SMCVO-CR

US Army Research Laboratory ATTN: AMSRL-OP-SD-FE

USAMC, Alexandria, VA 22333-0001 ATTN: AMCEN-F

National Guard Bureau ATTN: NGB-ARI ATTN: NGB-ARE ATTN: NGB-ARO-TS

Army National Guard Fort Richardson, AK 99505-5800 Montgomery, AL 36109-0711 Phoenix, AZ 85008-3495

N.Little Rock, AR 72199-9600

Camp Roberts, CA 93451

Sacramento, CA 95826-9101

Los Alamitos, CA 90720

Englewood, CO 80112

Hartford, CT 06105-3795

Washington, DC 20003-1719

Wilmington, DE 19808-2191

St. Augustine, FL 32085-1008

Starke, FL 32091

Atlanta, GA 30316-0965

Tamuning, GU 96911-4421

Honolulu, HI 96816-4495

Boise, ID 83705-8095

Springfield, IL 62702-2399

Indianapolis, IN 46241-4839

Johnston, IA 50131-1902

Topeka, KS 66611-1159

Frankfort, KY 40601-6168

New Orleans, LA 70146-0330

Camp Edwards, MA 02542-5003

Milford, MA 0175
Baltimore MD 21201-2288

Augusta, ME 04333-0033

Lansing, MI 48913-5101

Little Falls, MN 56345-0348

Jackson, MS 39209

Camp Shelby, MS 39407-5500

Jefferson City, MO 65101-905

Helena, MT 59604-4789

Lincoln, NE 68508-1090 (2)

Concord, NH 03301-5353

Trenton, NJ 08625-0340

Santa Fe, NM 87505

Carson City, NV 89701-5596

Raleigh, NC 27607-6410

Bismark, ND 58502-5511

Latham, NY 12110-2224

Columbus, OH 43235-2789

Camp Gruber, OK 74423

Oklahoma City, OK 73111-4389

Salem, OR 97309-5047

Annville, PA 17003-5002

San Juan, PR 00904

Providence, RI 02904-5717

Eastover, SC 29244

Columbia, SC 29201

Rapid City, SD 57702-8186

Austin, TX 78763-5218

Draper, UT 84020-1776

Richmond, VA 23219

Kings Hill, VI 00850-9764

Colchester, VT 05446-3004

Spokane, WA 99219-9069

Tacoma, WA 98430-5054

Madison, WI 53714-0587

Charleston, WV 25311-1085

Cheyenne, WY 82003

Headquarters, Army Environmental Ctr ATTN: SFIM-AEC-ECA

ATTN: SFIM-AEC-NR 21010

ATTN: SFIM-AEC-CR 64152

ATTN: SFIM-AEC-SR 30335-6801

ATTN: AFIM-AEC-WR 80022-2108

Tyndall AFB 32403

ATTN: HQAFCESA/CES

ATTN: Engrg \& Service Lab

Fort Belvoir 22060

ATTN: CETEC-IM-T

ATTN: CETEC-ES 22315-3803

ATTN: Water Resources Support Ctr

National Inst. of Stds and Technology ATTN: Library 20899

INSCOM 22186

ATTN: IALOG-I

ATTN: IAV-DPW

Information Systems Cmd ATTN: ASH-CPW-B

USATACOM

ATTN: AMSTA-XE

CEWES 39180

ATTN: Library

CECRL 03755

ATTN: Library

Military District of Washington, Fort McNair ATTN: ANEN 20319

US Military Academy 10996 ATTN: MAEN-A

ATTN: DOPS

ATTN: Facilities Enginee

ATTN: Geography \& Envr Engrg
Naval Facilities Engr Command

ATTN: Facilities Engr Command Code 03 (2)

Code 04

Code 20

Code 10

Code 03T

Code Fac-03

Code 21

ATTN: Division Offices, Northern Div

ATTN: Code 9A

ATTN: Code 1021/FLG

Chesapeake Division

ATTN: Code 0420374

Atlantic Division 23511 ATTN: Code 09B ATTN: Code 09A

Southern Division 29411 ATTN: RDT\&E Liaison Office (2)

Western Division 94066 ATTN: Code 203 ATTN: RDT\&E Liaison Officer

Pacific Division 96860 ATTN: Code 04B (2)

US Govt Printing Office 2040 ATTN: Rec Sec/Deposit Sec (2)

Defense Technical Info Ctr 22304 ATTN: DTIC-FAB (2)

274

$12 / 98$ 